\title{
The role of political uncertainty in Australian financial markets
}

\author{
Dr. Lee A Smales, CFA \\ School of Economics \& Finance, Curtin University \\ Building 402, Level 5 \\ Kent Street, Bentley \\ WA 6102 \\ Australia \\ Tel: +61 892661688 \\ Email: lee.smales@curtin.edu.au
}

Within the developed world, recent Australian political history is uniquely turbulent. This situation invokes indecision regarding investment decisions in both the real economy and financial markets. This paper explores the relationship between uncertainty in Australian federal election polling and resulting financial market uncertainty. Empirical evidence suggests that increasing (decreasing) levels of uncertainty around the election result induce higher (lower) levels of uncertainty in financial markets. The effect is more pronounced as polling day approaches. Industry level analysis suggests that the base materials sector is most significantly affected by election uncertainty.

Key-words: Political Uncertainty, Investor Sentiment, Implied Volatility, Exchange Traded Options, Stock Markets

JEL Classification Codes: G1, G10, G18, H3 


\section{Introduction}

Australian political history in the $21^{\text {st }}$ century has witnessed a tumultuous state of affairs that is unique among the world's developed countries. General elections have resulted in three changes in Government, while two additional changes of Prime Minister have arisen following party infighting ${ }^{1}$. By comparison to the five Australian Prime Ministers of the $21^{\text {st }}$ century, the U.K. and U.S. have had three heads of government, while Germany and New Zealand have had just two. In addition to the changes in political leadership, there have been media suggestions of a possible dissolution of Parliament to force through the Federal budget and changes in the tax system, along with the first hung Parliament since World War II.

Political uncertainty creates ambiguity within financial markets and this impacts the real economy through the investment and hiring decisions of firms. Pastor and Veronesi (2012 and 2013) make the first attempt at forming a theoretical model to explain this and theorise that uncertainty is created since the government can endogenously choose a "new" policy from a range of options at any time. The possibility of new options being chosen creates uncertainty as to whether policy will change, and also as to the magnitude of the impact of the policy change. Their model suggests that, independent of traditional risk factors, political uncertainty directly affects the risk premium. Within the Australian context, changes in carbon tax policy provide a fine example of how policy impact can be uncertain, even after announcement, as the stance of government shifts.

This paper seeks to answer a single fundamental question: Within the Australian context, what is the relationship between political uncertainty and financial market uncertainty? The Australian electoral system and political turmoil of the past decade provide an excellent setting within which to investigate this important question. The answer has repercussions for the cost of capital for corporations, and the portfolio decisions of investors.

Whilst the extant literature has primarily focused on how political uncertainty has influenced equity markets, the cost of capital for firms in an open economy is also affected by

\footnotetext{
${ }^{1}$ Julia Gillard became Australia's first female Prime Minister after replacing Kevin Rudd as leader of the Australian Labor Party (ALP) in June 2010. This result was reversed in another leadership ballot in June 2013. The Federal election of Sep 2013 saw a win for the Liberal National Party (L-NP) coalition and Tony Abbott became the third Australian Prime Minister in the space of just 84 days. Notably, the two changes in Prime Minister of June 2010 and June 2013 were determined by the ALP caucus and occurred without a public vote.
} 
interest rates and foreign exchange rates. Ingersoll and Ross (1992) show that the effect of interest rate uncertainty is important in understanding the investment decision, while Baker et al. (2013) show that an increase in economic policy uncertainty often leads to subsequent declines in investment, output and employment. A change in government, or government policy, will have an impact on bond yields, particularly through fiscal policy, and the value of the currency. To the extent that uncertainty in debt and currency markets affects the financing and investment decisions of firms, it is important to understand how such markets are affected by political uncertainty.

This paper contributes to the existing literature in several ways. Firstly, by extending analysis outside of the equity markets, a broader range of factors that affect firm decision-making and the real economy are considered for the first time. Second, existing work is placed in an Australian setting that has witnessed a period of political turmoil that is unique in the recent political history of developed countries. In contrast to the fixed 4-year term of the U.S. Presidential election cycle, an Australian federal election can be called at any time up to 3-years following the previous election, making it important to consider political uncertainty across all periods. Finally, in contrast to Goodell and Vähämaa (2013) who assume the outcome of the election is known a priori, polling data is used to construct a distinctive measure of ex-ante political uncertainty.

The empirical results establish a clear relationship between uncertainty in Australian financial markets and political uncertainty in the context of federal election polling. The implied volatility of equity, bond and currency options increases in line with uncertainty around the outcome of the federal election, particularly as polling day approaches. A link between rising asset prices and falling market uncertainty is also established. Examination of industry level volatility measures reveals that the volatility of stock returns for the basic materials sector (incorporating mining stocks) is significantly influenced by election uncertainty.

The remainder of this paper proceeds as follows. The second section provides an overview of the extant literature. Section three provides background information on the nature of Australian federal elections and also describes the data used in the empirical analysis. The fourth section presents methodology and reports empirical findings. Section five considers tests of robustness. Finally, section six provides concluding remarks. 


\section{Literature review}

Political factors influence both the returns and risk levels of financial assets, with market uncertainty tending to rise as the election approaches and as uncertainty about the result increases. Hibbs (1986) suggests that economic policies are conditioned by political forces, and party differences in policy have the potential to move the economy along different time paths and manifest in different returns to both stock- and bond-holders. Li and Born (2006) find that whilst the mean daily stock return rises in the 3-month period prior to U.S. elections when the outcome is uncertain, it is indistinguishable from the non-election period when the incumbent party is assured of re-election. Goodell and Vähämaa (2013) utilize data from the Iowa Electronic Market, a betting market for the U.S. Presidential election, to investigate the role of political uncertainty in a U.S. context. They find support for the political uncertainty hypothesis such that information regarding the probability of a particular election winner reflects information about future economic policy. Using the VIX volatility index as a proxy for stock market uncertainty, they somewhat surprisingly find a positive relationship between changes in the probability of success of the eventual winner and market uncertainty.

Gemmill (1992) discovers a close relationship between U.K. polling and the FTSE Stock Index, with some evidence of ill-informed option speculators creating a bubble in the week prior to the election. Pantzalis et al. (2000) report that the connection between political uncertainty and the stock market differs in countries of varying political, economic and press freedom. Bialkowski et al. (2008) investigate a sample of 27 OECD countries and find that investors are often surprised by the election outcome with the variance of stock market returns doubling during the week around the election. Importantly, the margin of victory and changes in political orientation of government are key factors in explaining the magnitude of the election shock. Boutchkova et al. (2012) find that some industries, particularly those more dependent on trade, contract enforcement, and labor exhibit greater sensitivity to political events than others. Julio and Yook (2012) provide evidence connecting political uncertainty to changes in fundamentals of the real economy as firms reduce expenditures during times of political uncertainty.

In terms of the impact that elections have on the macro-economy of a nation, this study fits within the more general field of research into the impact of news announcements and their effect on market uncertainty and volatility. The general result is that an upcoming scheduled news event induces an increase in market uncertainty that quickly dissipates once the 
announcement is made. Ederington and Lee (1996), Nikkinen and Sahlström (2004), and Smales (2013) report a rise in the volatility of financial asset prices as an approaching macroeconomic announcement creates uncertainty and then falls quickly when the data is released.

Vähämaa, Watzka and Äijö (2005) investigate how option-implied return distributions change for bond futures in-light of macroeconomic news announcements, and report that expected volatility increases in response to inflation and unemployment announcements. Nikkinen and Sahlström (2004), Chen and Clements (2007) and Vähämaa and Äijö (2011) examine the behaviour of implied volatility around FOMC monetary policy decisions and document that, having risen prior, implied volatility falls following the decision as uncertainty is resolved. Frijns et al. (2010) construct an implied volatility index for the Australian equity market and observe a significant and asymmetric relationship between the volatility index and stock returns, echoing prior findings in U.S. markets.

It is possible that in the case of elections that are not fixed in time, such as those in Australia, macroeconomic factors may be endogenous in terms of affecting the likelihood of an early election. Heckelman and Berument (1998) employ Hausman tests to find evidence in support of the view that election timing is a function of the economy in the U.K. and Japan. Julio and Yook (2012) find some limited evidence consistent with the view that governments opportunistically time elections if they have the option to do so. However, Alesina et al. (1992) examine several countries with flexible election timing and find no association between economic growth (GDP) and election timing in any country other than Japan. Wlezien et al. (1997) suggest that the effect of the economy on voter choice is substantially overstated, and thus the state of the economy should not rationally influence election timing. Boutchkova et al. (2012) discount the notion that party policy or any of their volatility measures are impacted by past economic performance.

\section{Data and Institutional Framework}

\subsection{Election Uncertainty in Australian Federal Polls}

The Australian Parliament was established in 1901 and voting is compulsory for all Australian citizens. While transferable proportional voting is used to elect the Senate (the upper house), it is the federal elections for the House of Representatives (the lower house) that are of interest in this study as the outcome of such elections forms the basis for Government. Although 
House elections must take place every 3 years, the incumbent Government may call an early election if it wishes. Whilst early elections, defined as those called more than 3-months prior to the 3-year maximum, were more common prior to 1990, the only one occurring in the sample period is that of 1998. The 2010 election brought the first hung parliament since 1940, with the Australian Labor Party holding on to power by virtue of the formation of a minority government.

Whilst the Australian political system consists of many political parties, only two have a realistic chance of winning sufficient representation in the House to form a government. As such, there is a de facto two-party system with the Australian Labor Party (ALP) toward the socialist (left) end of the political spectrum and the Liberal-National Party (L-NP) Coalition ${ }^{2}$ espousing more conservative (right) views. Traditionally, the ALP has had a predilection for fiscally expansionary policy that favours workers and unions, while the L-NP has in general favoured smaller government and policy that favours business. At the most basic level the differences between the leading Australian political parties are analogous in many ways to that between the Democratic (Labour) Party and the Republican (Conservative) Party in the U.S. (U.K.).

The voting system used in the House of Representatives is the two-candidate preferred vote. This is a full-preference instant runoff voting system in which voters are required to number candidates in their order of preference, and votes are re-distributed until an absolute majority is attained for each seat. An example serves to illustrate how this system works ${ }^{3}$. First, the number of first preference votes is counted and if a single candidate gains more than half the poll then that candidate will be elected. If no candidate has an absolute majority then the candidate with the fewest votes is excluded and the votes transferred to other candidates according to the second preferences shown by voters. This process is repeated until an absolute majority is found. The Australian Electoral Commission produces a two-candidate preferred result for every seat by completing a full distribution of preferences. For the vast majority of electorates (145 of 150 seats at the 2013 election) the two-candidate preferred vote is actually a two-party preferred (2PP) vote because the two leading candidates were endorsed by the ALP and the L-NP.

\footnotetext{
2 Officially, the Coalition consists of the Liberal Party of Australia, the National Party of Australia, the Liberal National Party and the Country Liberal Party.

3 A more detailed explanation can be found at the Australian Electoral Commission website: http://www.aec.gov.au/Voting/counting/hor count.htm
} 
While it is possible that minority parties, or independents, will win seats in the House of Representatives, the system of preferred voting means that it is virtually impossible for such parties to form Government. No minority party has held the balance of power in the post-war period, and in the sample period covered here no single minority party has won more than two lower House seats ( $1 \%$ of those available) in a single election, despite the Australian Greens often claiming $7 \%$ or more of the popular vote. The minority government formed by the ALP following the 2010 election relied on the declared support of three independent MPs to remain in power.

Owing to the nature of the Australian electoral system, two-party preferred voting data is of most interest when seeking to determine the likely winner of forthcoming elections, and this data is commonly referred to in political commentary from the Australian media. This study utilizes federal voting intention data expressed as a two-party preferred vote provided by Roy Morgan Research ${ }^{4}$. This polling data correctly predicted the victorious party in 6 out of the last 7 federal elections with only the unexpected L-NP win in 2001 proving the pollsters incorrect. A raft of studies (e.g. Erikson and Wlezien, 2008; Rothschild, 2009; Hillygus, 2011; Wright et al., 2013) in the political literature have considered whether opinion polls are worthwhile with the consensus being that they generally do a good job in predicting political outcomes provided there is a sufficient sample size.

In this study, the release of the poll is defined as the date on which it could begin to influence financial market returns. For example, if a poll is released on a Sunday then the next trading day is taken to be the poll date. During the sample period, polls are generally released on a fortnightly basis providing a base sample of 26 releases of polling data annually, to which is added additional weekly polls that take place in the period immediately prior to the election data. The frequency of polling, and the slightly different length of time between elections results in a small difference in the number of observations for each election cycle. Observations are aligned in terms of time from the election when constructing the data panel. To ensure consistency of the polling data, and well-known selection bias issues, telephone-based polls are excluded from the sample.

\footnotetext{
${ }^{4}$ Roy Morgan Research was founded in 1941 and as well as being the longest established public opinion polling company in Australia, is independent from ownership by any media companies, and it's opinion polls were most accurate in forecasting the outcome of the Australian federal elections during the timeframe considered in this study.
} 
This study introduces $E U_{n, t}$ as a measure of election uncertainty. $E U_{n, t}$ captures the difference between the likelihood of electoral victory, on a 2PP basis, of the L-NP and ALP for a given poll at tim $t$, during election cycle $n$. $E U_{n, t}$ is defined:

$$
E U_{n, t}=1-\left|P(L N P)_{n, t}-P(A L P)_{n, t}\right|
$$

Where $\mathrm{P}(L N P)_{n, t}$ denotes the probability of an election win for the L-NP coalition on the basis of $2 \mathrm{PP}$ and $\mathrm{P}(A L P)_{n, t}$ refers to probability of success for the ALP. A numerical example serves to illustrate the calculation of $E U_{n, t .}$. Consider the poll reported on $12^{\text {th }}$ February 1998 in which the $2 \mathrm{PP}$ vote is 52.5 for the ALP and 47.5 for the L-NP. $P(L N P)$ is calculated using the normal distribution with mean equal to 50.0 (since this is the minimum $2 \mathrm{PP}$ vote required to claim victory in the election), and standard deviation equal to 6.5 (the standard deviation of the difference in 2PP votes for the two parties). Hence, the $\mathrm{z}$-value for $P(L N P)$ is equal to 0.385 (52.5 -50.0 / 6.5) and equates to a success probability of 0.65 . Correspondingly, $P(A L P)$ is equal to 0.35 and $E U$ is $0.7(1-|0.65-0.35|)$. If the $2 \mathrm{PP}$ vote for the ALP increased to $58 \%$, as it did on $9^{\text {th }}$ August 1998, then $\mathrm{P}(A L P)$ becomes $0.91, \mathrm{P}(L N P)$ is just 0.09 , and $E U$ declines substantially to 0.18 as uncertainty over the election result is greatly reduced.

When both parties have an equal probability to become elected (i.e. $P(L N P)=P(A L P)=0.5$ ) then $E U$ equals one and election uncertainty is maximised. When either of the parties is certain to win the election (i.e. $P(L N P)=0$ or 1 or $P(A L P)=0$ or 1 ) then $E U$ equals zero and election uncertainty is minimized. $\mathrm{P}(\mathrm{LNP})+\mathrm{P}(\mathrm{ALP})$ is assumed to equal one for two reasons. First, minority parties are discounted since have so little influence on the formation of Government. Second, the polling data provided on a regular basis by Australian polling organisations only focuses on the $2 \mathrm{PP}$ vote for the two main parties. The test variable utilised within the empirical analysis is $\% \Delta E U_{n, t}$ - the percentage change in the electoral uncertainty measure. Goodell and Vähämaa (2013) use a similar measure but they incorporate the probability of the eventual winner to calculate uncertainty, and this is not known ex-ante.

\subsection{Financial Instruments and Macroeconomic Data}

The financial instruments utilized within the main section of the empirical analysis are exchange-traded options contracts based on the S\&P/ASX 200 (the leading benchmark for Australia's equity markets), and 10-year Treasury Bonds, along with over the counter (OTC) 
options on the AUD/USD exchange rate. Daily closing data is collected from Thomson Reuters Tick History (TRTH), provided by SIRCA5 , and the Australian Securities Exchange.

The main difference between realized volatility and implied volatility is that realized volatility is an ex-post measure of uncertainty while implied volatility is a measure of an ex-ante expectation of future uncertainty. Neely (2005) and Bauer (2012) find that uncertainty associated with expectations about future asset prices can be measured with implied volatility, while Chang and Feunou (2013) note that implied volatility is more informative if one is interested in assessing, on the day of an announcement, how the announcement changed expected market uncertainty. As such, implied volatility is a forward looking measure that incorporates all available information that is relevant for forming expectations about future volatility of asset prices, and is the preferred measure of uncertainty in this study.

A measure of implied volatility is constructed using the daily closing levels of ATM call and put options. The closing implied volatility level of the two nearest to expiry option contracts are interpolated in order to ensure a constant option maturity of 30 days. This produces a measure, $\sigma_{n, t}^{S P X}$, that represents the expected volatility of the S\&P/ASX 200 (SPX) over the next 30-days, and is similar in fashion to the widely used CBOE VIX index. Similarly, $\sigma_{n, t}^{10 Y B}$ and $\sigma_{n, t}^{A U D}$ represent the expected volatility of 10-yr Treasury bond futures, and the AUD/USD exchange rate, over the same period. Figure 1 illustrates the relationship between the two-party preferred vote for the ALP and the measures of market uncertainty over the sample period considered. Note the sharp fall in the ALP vote and the spike in equity market volatility around the geopolitical events of September 2001. Also of relevance is the apparent positive relationship between market uncertainty and support for the ALP during the 2007 and 2010 election campaigns. Support for the ALP increases (the incumbent L-NP decreased in support) prior to the 2007 election as market uncertainty increased, then market uncertainty and ALP support fall in the lead-up to the 2010 election.

$<$ Insert Figure 1>

In this study, the variables of interest are $\% \Delta \sigma_{n, t}^{S P X}, \% \Delta \sigma_{n, t}^{10 Y B}$, and $\% \Delta \sigma_{n, t}^{A U D}$ the percentage change in the implied volatility level of the S\&P/ASX 200 Index options 10-year Treasury Bond

\footnotetext{
${ }^{5}$ Securities Industry Research Centre of Asia-Pacific
} 
options, and AUD/USD options respectively. Where $n$ refers to the election cycle of interest and $t$ is the polling date within that cycle.

Changes in expectations regarding economic optimism will likely impact voting preferences, financial asset prices and market sentiment. In addition, prior literature (e.g. Fama and French, 1989; Engle et al., 2013) finds that macroeconomic variables may affect the volatility of market prices and so a number of macroeconomic variables are included as control variables. First, four variables are included to reflect macroeconomic growth trends and capacity constraints: \% $\triangle I N F L$ is the percentage change in inflation (CPI) as reported by the Australian Bureau of Statistics (ABS). Periods of increasing inflation are typically associated with increases in economic activity, increased financial market volatility, and more restrictive changes in monetary policy. $\% \triangle G D P$ is the percentage change in gross-domestic and \% $\% U N E M P$ is the monthly percentage change in unemployment reported by the ABS. \% $\triangle C O N S C O N F$ is the monthly percentage change in consumer confidence as reported by Westpac / Melbourne Institute, and it would be expected that rising consumer confidence would follow from rising stock markets and falling unemployment.

In addition, control variables are introduced to reflect changes in financial market prices that may reflect general levels of investor sentiment: $\% \Delta V I X$ is the percentage change in the CBOE Volatility Index which, although U.S. focused, is commonly used as an indicator of general financial market uncertainty. $\% \triangle A S X$ is the percentage change in the S\&P/ASX200 Index. $\% \triangle 3 m T B$ is the percentage change in the yield on 3-month Australian Treasury bills, and this is included as a measure of changes in monetary policy which influences many facets of economic activity. \% $\triangle A U D T W I$ is the percentage change in the trade-weighted-index of the Australian dollar. The change in slope of the yield curve, calculated as the difference between 3-month and 10-year Government yields, $\Delta$ YieldCurve is included since this provides information on market expectations of future economic activity and future changes in interest rates. Finally, Shi and Svensson (2006) report evidence of political budget cycles across the globe, with substantial fiscal deficit increases in election years. It is possible that changes in the budget deficit may influence the fiscal policy of any elected Government and so a measure (UDeficit) is introduced to capture this, with the data obtained from the RBA website.

$<$ Insert Table 1> 
Table 1 provides summary statistics for all of the variables used within the empirical analysis. Panel A provides information on the whole sample period, while Panel B focuses only on the observations falling within an election year. For the whole sample period the level of implied volatility in the stock market has generally been falling, while it has increased in the bond market and remained virtually unchanged on average in the currency market. Note that the standard deviation of changes is highest in the stock market. In election year the change in stock market uncertainty is of a lower magnitude while bond markets and especially currency markets exhibit larger increases in implied volatility. As one might expect, changes in election uncertainty also tend to be of a greater magnitude in election years.

Considering the statistics by election shows that the mean and standard deviation for all implied volatility measures was highest in the period prior to the 2007 federal election. Notably this election witnessed a loss at the polls for the incumbent L-NP. The mean value of the political uncertainty measures are relatively minor but exhibit a relatively large standard deviation. $\% \Delta E U$ was highest prior to the 2001 election that resulted in a surprising victory by the L-NP coalition ${ }^{6}$. The result of the election in each period is also shown, with the L-NP winning on four occasions, and the ALP on two.

Table 2 provides the Pearson correlation coefficients for the variables used in the regression analysis of this paper. Note the positive and significant correlation between $\% \Delta E U$ and the measures of implied volatility suggesting implied volatility increases as election uncertainty increases. There is a positive relationship between the implied volatility measures for equity, bond and currency markets which is indicative of changes in general investor uncertainty affecting all asset-classes. In a related matter, the measure of general market uncertainty (\% $\% I X)$ is positively and significantly correlated with changes in Australian financial market uncertainty. Consistent with Whaley (2009) there is a significantly negative relationship between $\% \triangle A S X$ and implied volatility measures, that is implied volatility rises as the stock market declines and vice-versa. Consistent with this idea of rising asset prices reducing market uncertainty, there is a negative correlation between the AUDTWI and implied volatility measures. Rising consumer confidence is consistent with a rising stock market (\% $\triangle A S X)$, while the correlations for other macroeconomic variables makes intuitive sense as rising interest rates $(\% \triangle 3 M T B)$ would likely be commensurate

\footnotetext{
${ }^{6}$ Examples of political events that resulted in the largest changes in election uncertainty are provided in Appendix A.
} 
with rising inflation, GDP and AUDTWI, along with falling unemployment. Finally, the negative correlation between short-term interest rates and the yield curve is consistent with the observation that the yield curve tends to flatten (steepen) as short-term rates are increased (decreased).

$<$ Insert Table 2>

\section{Empirical Results}

\subsection{Implied Volatility and Political Uncertainty}

This section presents the results of the empirical investigation into the relationship between political uncertainty and implied volatility. The first stage in the empirical analysis involves a panel regression of the form:

$$
\% \Delta \sigma_{n, t}^{i}=\alpha+\beta_{1} \% \Delta E U_{n, t}+\beta_{3} \% \Delta \sigma_{n, t-1}^{i}+\varepsilon_{n, t}
$$

Where $\% \Delta \sigma_{n, t}^{i}$ is the percentage change in implied volatility of instrument $i$ (exchangetraded options on the S\&P/ASX 200, the 10-yr government bond, or the AUD/USD exchange rate) at time $t$ in election cycle $n, \% \Delta E U_{n, t}$ is the percentage change in election uncertainty, and $\varepsilon_{n, t}$ is the robust error term. A one-period lagged percentage change in implied volatility is included since the volatility of the financial instruments considered is generally mean-reverting.

\section{$<$ Insert Table 3>}

Table 3 - Panel A reports the results for the regression ${ }^{7}$ presented in Eq. (2). Since it is possible that an Australian election may be called early, in the first instance, it is important to consider all time periods within the sample, and not only those that occur as the 3-year limit is reached and election day approaches. Indeed, even if an election is not called early, changes in the election uncertainty term may be interpreted as changes in the political spectrum that may influence economic policy. For instance, large changes in election uncertainty occurred around each of the Rudd-Gillard ALP leadership challenges that resulted in a change of Prime Minister. The results prove a clear indication that the level of implied volatility increases as election uncertainty increases. The magnitude of the effect is greatest for SPX options where a $1 \%$ increase in election uncertainty results in a $0.515 \%$ increase in SPX implied volatility. In comparison, the

\footnotetext{
${ }^{7}$ Hausman tests are conducted for each regression specification in order to ascertain whether a fixed-effects or random-effects model is more efficient. Based on those tests the random effects estimates are reported throughout the analysis.
} 
same change in election uncertainty finds a $0.275 \%$ increase in 10 -year bond implied volatility, and just a $0.228 \%$ increase in AUD/USD implied volatility.

It is possible that election uncertainty is most important to financial market participants as election-day approaches and two specifications are used to examine this. Note that the terms introduced must acknowledge that the specific election date is not known a priori. First, a dummy variable (Election Year) is introduced that takes a value of 1 if the observation is in the year preceding the due date of an election, and 0 otherwise. Second, while it is not possible to know the number of days until the election, market participants know the number of days since the last election $(D S L E)$ and as that period increases the next election will draw closer. Positive and strongly significant interaction terms between $\% \Delta E U$ and the two factors indicating polling day closeness provide solid evidence to suggest that it is election uncertainty in proximity to polling day that is most important for Australian financial markets. For SPX options, a $1 \%$ increase in election uncertainty during the election year induces a $0.84 \%$ increase in implied volatility.

A disaggregation of the model specified in eq. (2) into each election period is presented in Table 4 to allow for analysis of how the relationship has evolved over time. Without the election year interaction term, consideration of the election-specific model suggests that the influence of election uncertainty on implied volatility is declining over time for bond and equity options, and increasing for AUD/USD options. However, when the interaction term is included, it is apparent that election uncertainty has a significant impact on all options and in the majority of elections. Again, this is supportive of the notion that it is election uncertainty in the period leading up to polling day that is most important for financial markets.

$<$ Insert Table 4>

The magnitude of the interaction coefficients is highest for the 2001 election when L-NP held on for a surprising win and in the 2010 election when a hung-parliament occurred (creating possible post-election uncertainty) suggesting that the closeness of the vote, may be related to election and market uncertainty. The election year interaction with election uncertainty is not significant for any of the instruments in 2007. Referring to Fig. 1 it is clear that ALP held a significant lead over the L-NP throughout the election cycle resulting in low levels of electoral uncertainty. Replacing the election year interaction term with a term indicating the number of days since the last election provides qualitatively similar results. 
In summary, consistent with Li and Born (2006) and Bialkowski et al. (2008), there is strong evidence that election uncertainty has a significant impact on market uncertainty. The defined election uncertainty measure exhibits a significant and positive relationship with implied volatility, with the strength of the relationship related to the proximity of the election. The equity market appears to have the strongest association with election uncertainty and this may be explained by equity markets having a greater proportion of retail investors who are more likely influenced by media attention on opinion polls. The results are analogous to the general finding that important scheduled news events create market uncertainty which is only resolved when the outcome is known.

\subsection{The influence of macroeconomic factors}

The extant literature demonstrates that a range of macroeconomic factors have an influence on levels of implied volatility and market uncertainty. Macroeconomic variables are introduced into the model specification in order to examine whether the impact of political uncertainty remains when controlling for economic conditions. A model is specified as follows:

$$
\begin{aligned}
& \% \Delta \sigma_{n, t}^{i}=\alpha+\beta_{1} E_{n, t}+\beta_{2} \% \Delta E U \cdot \text { ElectionYear }_{n, t}+\beta_{3} \Delta \text { Deficit }+\beta_{4} \% \Delta V I X_{n, t} \\
& +\beta_{5} \% \Delta I N F L_{n, t}+\beta_{6} \% \Delta U N E M P_{n, t}+\beta_{7} \% \Delta G D P_{n, t}+\beta_{8} \% \Delta A S X_{n, t} \\
& +\beta_{9} \% \Delta \text { CONSCONF }_{n, t}+\beta_{10} \% \Delta 3 M T B_{n, t}+\beta_{11} \% \Delta A U D T W I_{n, t} \\
& +\beta_{12} \Delta \text { YieldCurve }_{n, t}+\beta_{13} \% \Delta \sigma_{n, t-1}^{i} \\
& +\varepsilon_{n, t}
\end{aligned}
$$

Where $\% \Delta \sigma_{n, t}^{i}$ is the percentage change in implied volatility of instrument $i$ (exchangetraded options on the S\&P/ASX 200, the 10-yr government bond, or the AUD/USD exchange rate), $\% \Delta E U_{n, t}$ is the percentage change in election uncertainty, and $\% \Delta E U \cdot$ ElectionYear $_{n, t}$ is an interaction term indicating election uncertainty in the year prior to an election. A number of macroeconomic variables are also included along with a lagged dependent variable. The regression results for Eq. (3) are reported in Table 5. For each asset-class Model 1 contains only the general measure of election uncertainty (\% $\% E U$ ), while Model 2 and 3 augment this specification with alternate election uncertainty variables indicative of election-day proximity.

$<$ Insert Table 5>

Consider the results for SPX equity options first. Election uncertainty has a significant and positive impact on uncertainty in the equity market. As one would expect given the crosscorrelations highlighter earlier, there is a significant negative relationship between changes in the 
stock market level (\% $\% A S X)$ and implied volatility in SPX options; a $1 \%$ increase in the stock market reduces implied volatility by $1.99 \%$. This result is also consistent with Whaley (2009) who reports a negative relationship between equity market returns and levels of implied volatility. Given the interaction between global equity markets there is no surprise that there is a significant positive relationship between $\% \Delta V I X$, which is a measure of implied volatility on U.S. stocks, and the implied volatility on Australian stocks $(\% \Delta \sigma S P X)$. The $\mathrm{AR}(1)$ variable is significant and negative indicating mean-reversion, whereby increases in volatility in one-period are followed by declines in the next.

The positive and significant coefficient for $\Delta$ YieldCurve may be explained by the literature concerning economic activity and asset prices. A number of studies (e.g. Asness, 2000; Campbell and Vuolteenaho, 2004) point to higher levels of inflation explaining poor stock returns and inducing stock market volatility. According to Estrella and Hardouvelis (1991), a steepening (flattening) yield curve tends to predict a future increase (decrease) in real economic activity, thus sharp increases in $\triangle$ YieldCurve, and $\triangle G D P$ may be indicative of future inflation. Consistent with this idea of inflation driving market volatility, positive coefficients are noted for inflation, GDP and the yield curve although only that for the yield curve is significant. While the signs of the coefficients for macroeconomic variables are in the expected direction, they do not have a significant impact on implied volatility levels. Augmenting the specification (Model 2 and Model 3) confirms that the results from the previous section hold even after controlling for macroeconomic variables. That is, election uncertainty, particularly in proximity to the coming election, has a significant and positive impact on market uncertainty. In this specification $\Delta$ Deficit becomes significant at the $10 \%$ level. This is consistent with expansionary fiscal policy (increasing $\Delta$ Deficit) being inflationary and thus inducing higher market volatility.

The results for the bond market are broadly similar, with election uncertainty having a positive and significant influence on implied volatility that is stronger in election years. Higher inflation and short-term yields are generally negative for bond prices, accordingly positive and significant coefficients are consistent with lower (higher) prices positively (negatively) effecting market volatility. In the same way, increasing $A U D T W I$ is suggestive of foreign investors purchasing Australian assets and pushing up bond prices, and lowering bond market option volatility. Again, the AR(1) term is negative and well-defined. None of the other macroeconomic 
variables are significant, and notably this includes changes in the stock market, and changes VIX which is often viewed as a proxy for general market uncertainty.

Findings in the AUD/USD market are generally consistent with the other two markets although there are subtle differences. Election uncertainty has a well-defined and positive relationship with market uncertainty. In a similar vein to the stock and bond markets, volatility in the currency market declines as the asset (AUD) appreciates. A 1\% increase in the AUDTWI results in a $1.37 \%$ fall in implied volatility. Consistent with this view, there is a negative and significant coefficient for $\% \triangle A S X$ that may be explained by increasing demand (and higher prices) for the AUD from foreign investors to buy Australian stocks that reduces implied volatility in the currency market. Changes in VIX have a significant and positive influence on AUD implied volatility. Two reasons may be put forward to explain this relationship. First, VIX may be acting as a measure for general market uncertainty that is correlated with levels of currency market uncertainty. Second, Brunnermeier et al. (2008) claim that higher levels of VIX may trigger a flight of quality toward the USD and lead speculative investors to unwind carry trades and resulting in AUD depreciation. The AUD has proven to be a major investment currency owing to the relatively high level of interest rates. The $\mathrm{AR}(1)$ term is negative but not significant for the AUD market.

To summarize, the statistically significant impact of election uncertainty on implied volatility remains even after controlling for such macroeconomic variables. For equity, bond, and currency options the proximity of the election uncertainty to the actual polling date is important. The significance of changes in the stock market, the AUDTWI, and VIX is a common factor in at least two of the three markets. This indicates that rising (falling) stock markets, appreciating (depreciating) AUD, and falling (rising) levels of general uncertainty are suggestive of decreases (increases) in market uncertainty and investor sentiment. Finally, there is evidence to support the view that rising asset prices result in lower levels of implied volatility.

\subsection{Effect of political uncertainty at an industry level}

So far this paper has focused on the asset-level impact of election uncertainty owing to the interest in aggregate activity. However, as Boutchkova et al. (2012) report, it is possible that election uncertainty may influence stocks in disparate industries to differing extents. It is therefore appropriate to extend the analysis to examine whether political uncertainty plays a 
larger role in some industries than it does in others. Since option implied volatility incorporates all available information that is relevant for forming expectations about future volatility, it has formed the focus of the analysis to this stage. However, for the majority of firms in the Australian stock market there are no traded options ${ }^{8}$ and therefore it is not possible to accurately estimate implied volatility measures across industries. Instead, to facilitate an industry level analysis, the implied volatility measure is replaced by the average standard deviation of returns of the stocks in each industry during period $t$, that is realized volatility. Stocks are classified into 10 industry sectors using the Global Industry Classification Standard (GICS).

$<$ Insert Table 6>

Table 6 - Panel A reports the results for the industry level analysis utilising the model specification of Eq.(2) with realized industry level volatility as the dependent variable. In general, election uncertainty serves to increase the volatility of returns across all industries, apart from the health-care industry. However, the coefficients are only statistically significant for the basic materials sector which includes metals and mining stocks, where a $1 \%$ increase in election uncertainty is associated with a $0.45 \%$ increase in volatility. In addition, changes in election uncertainty have an even greater impact on realized volatility in the basic materials industry during election year. Examination of the data for each election indicates that this relationship is primarily driven by the results for the 2007 and 2010 elections ${ }^{9}$. While specifically testing the rationale for this in the manner of Boutchkova et al. (2012) is outside the scope of this paper it is possible to provide at least one potential explanation. The ALP campaign for the 2007 election concerned efforts to reduce emissions and the introduction of a carbon tax, while the 2010 campaign involved continued debate about the introduction of a mineral rent resource tax (commonly known as a mining tax). Such policy changes would naturally be expected to have the largest impact on the basic materials sector.

The specification is augmented with macroeconomic variables and the results reported in Table 6 - Panel B. The addition of macroeconomic variables greatly increases the explanatory power of the model. The relationships identified for each industry are broadly similar to those

\footnotetext{
${ }^{8}$ As of September 2013, only 60 of the ASX 200 constituents have traded options, with the majority of trading liquidity concentrated within a few of those stocks. The average number of companies with traded options during each interval of the sample period is much lower and so adequate measures of implied volatility are not possible to gauge.

${ }^{9}$ For conciseness the additional tables are not reported here but are available from the author on request.
} 
identified for the overall equity market using SPX options. In particular, changes in inflation, GDP, unemployment and the yield curve have a positive relationship, while changes in the overall level of the stock market and consumer confidence have a negative relationship. However, the significance of the variables is reduced with the Financial sector having the only well-defined $\% \triangle A S X$ and $\triangle$ YieldCurve coefficients.

The most important variable for explaining changes in uncertainty at the industry level appears to be changes in general market uncertainty $(\% \Delta V I X)$ as this is positive and significant for all industries. This implies that as VIX increases, then so does realized volatility within each of the identified sectors. Two other macroeconomic variables have significant relationships: First, the value of the AUD impacts volatility in the basic materials, industrials, and energy sectors, with increases in the value of the AUD reducing volatility. This is likely consistent with those sectors been reliant on inputs and sales priced in USD. The fiscal deficit has a significant positive relationship with volatility in the basic materials, consumer goods, consumer services, financials, industrials, and technology sector. This may be the result of such industries been exposed to demand and supply shifts as a result of changes in fiscal policy, whilst the unaffected industries (Utilities, Health Care, Energy, and Telecoms) have sales that are less related to discretionary spending and as such are more immune from such policy changes. Importantly, even after controlling for macroeconomic variables, economic uncertainty remains a statistically significant factor in explaining changes in the volatility of the basic materials sector, and this relationship is particularly strong in the election year.

It may be surprising that only one sector is significantly impacted by election uncertainty while analysis in the prior sections revealed that the Australian stock market in general was influenced by such uncertainty. Two explanations offer themselves: First, the dependent variable here is realized volatility and not implied volatility. Second, the basic materials sector accounts for nearly $20 \%$ of the ASX and this sector may drive a substantial portion of the earlier identified relationship.

In summary, industry analysis indicates that changes in general market uncertainty are strongly related to the level of realized volatility in stock returns at the industry level. In addition, the fiscal deficit and the strength of the Australian dollar have a significant influence on the volatility of several Australian industries that have input and sales price exposure to such factors. The realized volatility of the basic materials sector is the only one that appears to have a 
significant relationship with election uncertainty and this may largely be due to the policy uncertainty surrounding the outcome of the 2007 and 2010 federal elections.

\section{Robustness Tests}

\subsection{Non-linearity of election uncertainty influence}

The previous section demonstrated the importance of the political uncertainty - financial market uncertainty relationship. However, it may be that the marginal effect of political uncertainty is dependent on the size of the change in political uncertainty. For instance, extremely large increases in political uncertainty may have a smaller impact on market uncertainty than do decreases. A quadratic term for changes in election uncertainty is introduced to model the potential non-linearity of the relationship. Results reported in Table 7 show that the quadratic term is negative and significant for stock and bond market, while the term is positive and significant for the currency market. This implies that decreases in political uncertainty have a relatively larger impact on market uncertainty for stocks and bonds, while increases have a greater impact on the currency market. However, at approximately $1 \%$ of the size of the linear term, the magnitude of the quadratic coefficient suggests that the economic impact is very small.

\section{$<$ Insert Table 7>}

\subsection{Control in upper and lower houses}

A final question to consider is whether control of both the upper house (Senate) and lower house (House of Representatives) by the incumbent party has an effect on the influence of political uncertainty on market uncertainty. It is not clear what impact that such control in both houses will have on political uncertainty since whilst more control would lead to a lower level of uncertainty regarding policy direction, it would also increase the likelihood of policy changes passing into law. As it happens, the proportional representation voting system of the Senate makes it very difficult for any political party to gain majority control. The L-NP has held the most seats in the Senate in every year since 1993, but has had an outright majority on only one occasion (2005-2008), a period during which it lost the lower house election ${ }^{10}$. Regression tests utilising variables for senate control including the number of seats controlled by the lower House incumbent, and whether there was control of both houses, produced no significant results. Whilst

\footnotetext{
${ }^{10}$ The term of office for a Senator lasts six years, and only half of the seats tend to be available for election at the time of each federal election.
} 
the sample size is limited, this is suggestive of control in both houses not been a significant factor in determining political uncertainty, at least not in the context employed in this paper.

\section{Conclusion}

This study examines the effects of political uncertainty on implied volatility, and by implication market uncertainty, during Australian federal election cycles. Utilizing polling data from Roy Morgan Research, empirical measures of political uncertainty are constructed over six Australian election cycles between 1998 and 2013 in order to examine a single key proposition.

The empirical results indicate that Australian federal election uncertainty has a significant impact on market uncertainty. In particular, the implied volatility of equity, bond and currency options increases in line with uncertainty about the election outcome as polling day draws near. Since increased uncertainty, manifested in increased volatility, results in a higher cost of capital, this has implications for corporations looking to raise finance or make investment decisions in proximity to election dates, and also for investors making portfolio decisions.

Examination of industry level volatility measures reveals that the volatility of stock returns for the basic materials sector (incorporating mining stocks) is significantly influenced by election uncertainty. One explanation for this result may relate to this sector having been at the centre of political wrangling during the sample period, particular over the introduction of the Mineral Rent Resource Tax (popularly referred to as the Mining Tax) which is a tax on corporate profits generated from the exploitation of non-renewable resources in Australia.

$$
<\text { Appendix A> }
$$

\section{References}

Alesina, A., G.D. Cohen, and N. Roubini, 1992, Macroeconomic policy and elections in OECD democracies, Economics and Politics, 5, 1-30

Asness, C., 2000, Stocks versus bonds: Explaining the equity risk premium, Financial Analysts Journal, 56, 96-113

Baker, S.R., N. Bloom, and S.J. Davis, 2013, Measuring economic policy uncertainty, Working Paper, Stanford University and University of Chicago

Bauer, M.D., 2012, Monetary policy and interest rate uncertainty, FRBSF Economic Letter, 38

Bialkowski, J., K. Gottschalk, and T.P. Wisniewski, 2008, Stock market volatility around national elections, Journal of Banking and Finance, 32, 1941-1953 
Boutchkova, M., H. Doshi, A. Durnev, and A. Molchanov, 2012, Precarious politics and return volatility, Review of Financial Studies, 25, 1111-1154

Brunnermeier, M.K., S. Nagel, and L.H. Pedersen, 2008, Carry trades and currency crashes, NBER Macroeconomics Annual, 23, 313-347

Campbell, J.Y., and T. Vuolteenaho, 2004, Inflation illusion and stock prices, American Economic Review, 94, 19-23

Chang, B.Y., and B. Feunou, 2013, Measuring uncertainty in monetary policy using implied volatility and realized volatility, Working Paper, Bank of Canada

Chen, E.T., and A. Clements, 2007, S\&P 500 implied volatility and monetary policy announcements, Finance Research Letters, 4, 227-232

Ederington, L.H. and J.H. Lee, 1996, The creation and resolution of market uncertainty: The impact of information releases on implied volatility, Journal of Financial and Quantitative Analysis, 31, 513-539

Engle, R.F., E. Ghysels, and B. Sohn, 2013, Stock market volatility and macroeconomic fundamentals, Review of Economics and Statistics, 95, 776-797

Erikson, R.S., and C. Wlezien, 2008, Are political markets really superior to polls as election predictors? Public Opinion Quarterly, 72, 190-215

Estrella, A., and G.A. Hardouvelis, 1991, The term structure as a predictor of real economic activity, Journal of Finance, 46, 555-576

Fama, E.F., and K.R. French, 1989, Business conditions and expected returns on stocks and bonds, Journal of Financial Economics, 25, 23-49

Frijns, B., C. Tallau, A. Tourani-Rad, 2010, The information content of implied volatility: Evidence from Australia, Journal of Futures Markets, 2010, 30, 134-155

Gemmill, G., 1992, Political risk and market efficiency: Tests based in British stock and options markets in the 1987 election, Journal of Banking and Finance, 16, 211-231

Goodell, J.W., and S. Vähämaa, 2013, US presidential elections and implied volatility: The role of political uncertainty, Journal of Banking and Finance, 27, 1108-1117

Heckelman, J.C., and H. Berument, Political business cycles and endogenous elections, Southern Economic Journal, 64, 987-1000

Hibbs, D., 1986, Political parties and macroeconomic policies and outcomes in the United States, American Economic Review, 66-70

Hillygus, D.S., 2011, The evolution of election polling in the United States, Public Opinion Quarterly, 75, 962-981 
Ingersoll, J.E. and S.A. Ross, 1992, The value of waiting to invest: Investment and uncertainty, Journal of Business, 65, 1-29

Julio, B., and Y. Yook, 2012, Political uncertainty and corporate investment cycles, Journal of Finance, 67, 45-83

Li, J., J.A. Born, 2006, Presidential election uncertainty and common stock returns in the United States, Journal of Financial Research, 29, 609-622

Neely, C.J., 2005, Using implied volatility to measure uncertainty about interest rates, Federal Reserve Bank of St. Louis Review, 87 (3), 407-425

Nikkinen, J., and P. Sahlström, 2004, Impact of the Federal Open Market Committee's meetings and scheduled macroeconomic news on stock market uncertainty, International Review of Financial Analysis, 13, 1-12

Pantzalis, C., D.A. Strangeland, and H.J. Turtle, 2000, Political elections and the resolution of uncertainty: the international evidence, Journal of Banking and Finance, 24, 1575-1604

Pastor, L., and P. Veronesi, 2012, Uncertainty about Government policy and stock prices, Journal of Finance, 67, 1219-1264

Pastor, L., and P. Veronesi, 2013, Political uncertainty and risk premia, Journal of Financial Economics, 110, 520-545

Rothschild, D., 2009, Forecasting elections, Public Opinion Quarterly, 73, 895-916

Shi, M., and J. Svensson, 2006, Political budget cycles: Do they differ across countries and why? Journal of Public Economics, 90, 1367-1389

Smales, L.A., 2013, Impact of macroeconomic announcements on interest rate futures: Highfrequency evidence from Australia, Journal of Financial Research, 36, 371-388

Vähämaa, S., S. Watzka, and J. Äijö, 2005, What moves option-implied bond market expectations, Journal of Futures Markets, 25, 817-843

Vähämaa, S., and J. Äijö, 2011, The Fed's policy decisions and implied volatility, Journal of Futures Markets, 31, 995-1009

Whaley, R.E., 2009, Understanding the VIX, Journal of Portfolio Management, 35, 98-105

Wlezien, C., M. Franklin, and D. Twiggs, 1997. Economic perceptions and vote choice: Disentangling the endogeneity, Political Behavior, 19, 7-17

Wright, M.J., D.P. Farrar, and D.F. Russell, 2013, Polling accuracy in a multi-party election, International Journal of Public Opinion Research, doi:10.1093/ijpor/edt009 
Figure 1

Relationship between Financial Market and Political Uncertainty

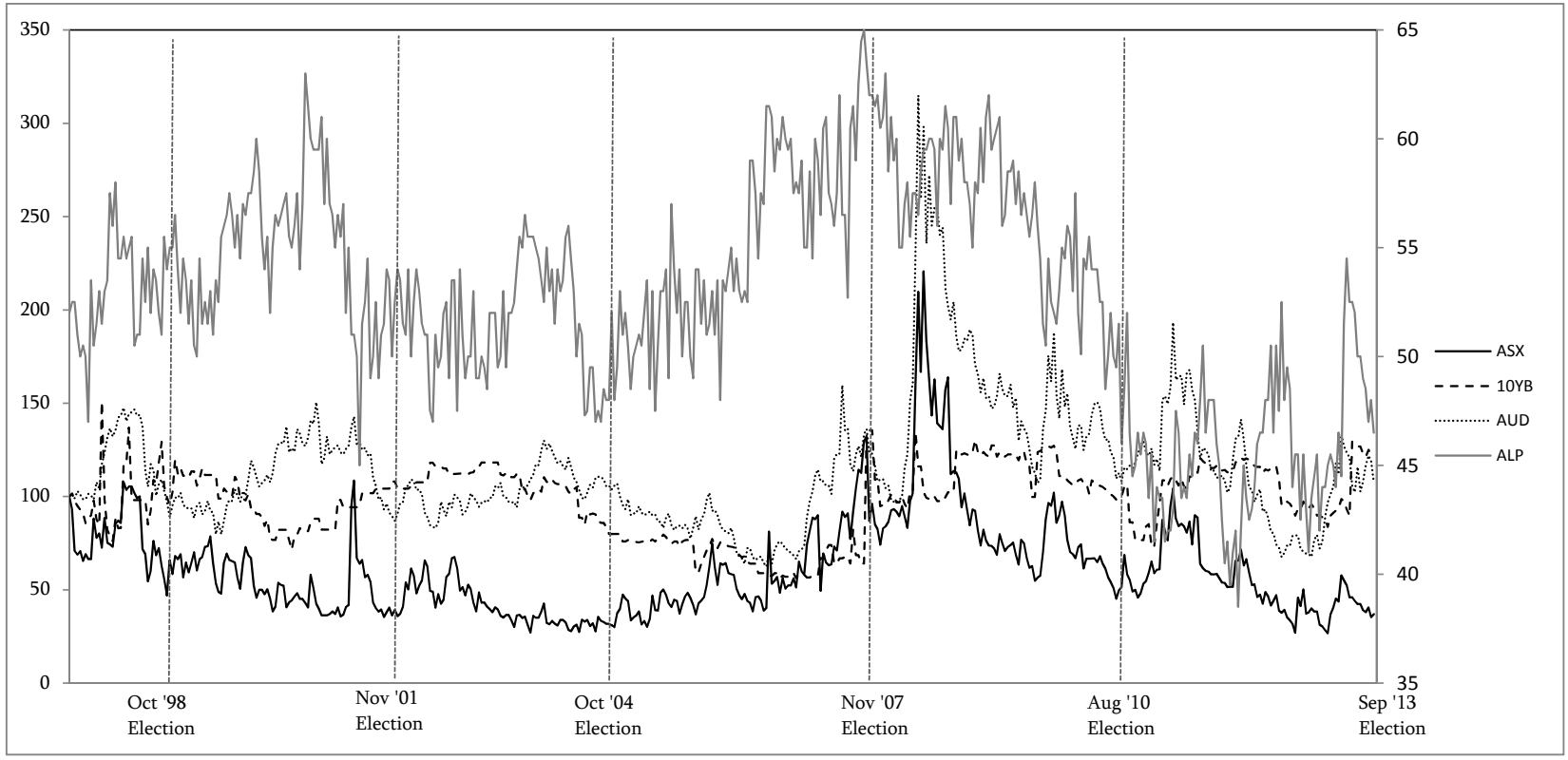

This figure depicts the evolution of financial market uncertainty and political uncertainty over the period 1998-2013. Financial market uncertainty, displayed on the LHS axis, is represented by the implied volatility of options in the ASX equity options ( $A S X)$, 10-yr bond options $(10 Y B)$, and AUD/USD currency options $(A U D)$. Political uncertainty, displayed on the RHS axis, is represented by the two-party preferred vote percentage for the Australian Labor Party $(A L P)$. The vote for the Liberal-National Party $(L N P)$ is simply 100 - ALP. 


\section{Appendix A}

Political news events explaining largest changes in political uncertainty

\begin{tabular}{|c|c|c|c|c|c|c|}
\hline Rank & Date & $\% \Delta E U$ & $\% \Delta \sigma_{S P X}$ & $\% \Delta \sigma_{10 Y B}$ & $\% \Delta \sigma_{A U D}$ & Relevant political news \\
\hline 1 & $27 / 05 / 2012$ & 15.60 & 24.07 & 4.66 & 9.12 & Former ALP MP C. Thompson denies corruption charges in Parliament \\
\hline 2 & $12 / 11 / 2007$ & 13.52 & 11.90 & 2.09 & 26.07 & $\begin{array}{l}\text { Focus on economy as RBA increase interest rates, and global economy appears to be } \\
\text { entering a period of instability. }\end{array}$ \\
\hline 3 & $17 / 09 / 2001$ & 13.06 & 95.04 & 10.80 & 11.47 & $\begin{array}{l}\text { First poll after } 9 / 11 \text { attacks in USA. Following the terrorist attack in the US the image of } \\
\text { Mr Howard, who was in Washington at the time, was "significantly enhanced" as voters } \\
\text { view L-NP as tougher on national security. }\end{array}$ \\
\hline 4 & $27 / 08 / 2007$ & 12.88 & 1.96 & 16.21 & 7.64 & $\begin{array}{l}\text { Concerns over U.S. subprime market pushes voters towards the L-NP coalition for } \\
\text { whom "economic management" is viewed as a major strength. }\end{array}$ \\
\hline 5 & $16 / 08 / 2010$ & 12.17 & 8.61 & 1.49 & 9.50 & $\begin{array}{l}\text { Gillard / Rudd reconcilliation in Brisbane generates poor publicity, appearing 'stage- } \\
\text { managed'. Former ALP leader M. Latham confronts PM Gillard. }\end{array}$ \\
\hline 6 & $15 / 03 / 2009$ & 11.06 & 1.41 & 20.13 & 4.82 & Reshuffle in shadow cabinet (LNP) \\
\hline 7 & $9 / 11 / 2009$ & 10.79 & 8.73 & 2.99 & 2.47 & $\begin{array}{l}\text { Media attention critical of "boat-people" policy, followed by Melbourne Cup day } \\
\text { increase in interest rates. }\end{array}$ \\
\hline 8 & $16 / 07 / 2000$ & 10.30 & 5.43 & 3.99 & 2.62 & First poll following the introduction of goods and services tax (GST). \\
\hline 9 & $16 / 07 / 2007$ & 9.31 & 25.08 & 9.88 & 18.88 & $\begin{array}{l}\text { First poll after Brisbane Doctor Mohammed Haneef is taken into custody concerning } \\
\text { terror plots; L-NP gains support as is viewed to be stronger on national security. }\end{array}$ \\
\hline 10 & $20 / 07 / 2008$ & 9.31 & 5.88 & 1.03 & 1.94 & Debate over carbon emission policy \\
\hline
\end{tabular}

Note: This table depicts the 10 largest increases in political uncertainty $(\% \Delta E U)$ during the sample period, together with associated changes in financial market uncertainty and related news items. The relevant political news is taken from the information provided to pollsters (Roy Morgan) on the given date. 
TABLE 1

Summary Statistics for implied volatility, political and macroeconomic variables

\begin{tabular}{|c|c|c|c|c|c|c|c|c|c|c|c|c|c|c|}
\hline \multirow{2}{*}{$\begin{array}{c}\text { Panel A: Whole } \\
\text { Sample }\end{array}$} & \multicolumn{2}{|c|}{ Overall } & \multicolumn{2}{|c|}{1998 Election } & \multicolumn{2}{|c|}{2001 Election } & \multicolumn{2}{|c|}{2004 Election } & \multicolumn{2}{|c|}{2007 Election } & \multicolumn{2}{|c|}{2010 Election } & \multicolumn{2}{|c|}{2013 Election } \\
\hline & Mean & Std Dev & Mean & Std Dev & Mean & Std Dev & Mean & Std Dev & Mean & Std Dev & Mean & Std Dev & Mean & Std Dev \\
\hline$\% \Delta \sigma_{\text {SPX }}$ & -0.33 & 14.22 & -0.04 & 11.55 & -0.79 & 18.13 & -0.67 & 12.41 & 1.25 & 13.08 & -0.27 & 13.88 & -1.24 & 13.78 \\
\hline$\% \Delta \sigma_{10 \mathrm{YB}}$ & 0.15 & 8.85 & -0.09 & 20.52 & -0.01 & 6.20 & -0.20 & 2.98 & 0.04 & 6.02 & 0.76 & 11.60 & 0.22 & 9.40 \\
\hline$\% \Delta \sigma_{\text {AUD }}$ & 0.01 & 7.45 & 1.71 & 4.00 & -0.20 & 6.72 & -0.30 & 4.48 & 0.36 & 6.55 & 0.02 & 10.52 & -0.31 & 8.52 \\
\hline$\% \Delta \mathrm{EU}$ & -0.05 & 4.81 & 0.34 & 4.52 & 0.00 & 5.11 & -0.04 & 3.51 & -0.02 & 5.18 & -0.03 & 5.72 & -0.24 & 4.42 \\
\hline$\% \Delta$ VIX & -1.00 & 14.98 & 2.60 & 14.81 & -0.41 & 13.99 & -0.93 & 12.68 & 0.87 & 13.64 & -0.16 & 16.26 & -0.61 & 17.96 \\
\hline$\% \Delta \mathrm{INFL}$ & 0.07 & 0.72 & 0.47 & 0.38 & 0.26 & 0.97 & -0.06 & 0.57 & -0.05 & 0.49 & 0.13 & 0.90 & -0.06 & 0.54 \\
\hline$\% \Delta \mathrm{UNEMP}$ & -0.25 & 2.86 & -0.06 & 2.08 & -0.47 & 2.76 & -0.65 & 2.78 & -0.74 & 2.20 & 0.32 & 3.80 & 0.22 & 2.68 \\
\hline$\% \Delta$ GROWTH & -0.03 & 0.82 & 0.09 & 1.27 & -0.28 & 0.92 & 0.27 & 0.80 & 0.07 & 0.65 & -0.26 & 0.69 & 0.01 & 0.76 \\
\hline$\% \Delta \mathrm{ASX}$ & 0.18 & 3.13 & -0.21 & 3.17 & 0.45 & 2.65 & 0.15 & 2.08 & 0.69 & 2.09 & -0.51 & 5.03 & 0.19 & 2.89 \\
\hline$\% \Delta \mathrm{CONSCONF}$ & -0.12 & 5.48 & -0.55 & 5.34 & -0.07 & 5.24 & 0.53 & 3.66 & -0.80 & 6.90 & 0.42 & 6.60 & -0.49 & 4.37 \\
\hline$\% \triangle 3 \mathrm{MTB}$ & -0.14 & 2.85 & -0.14 & 3.48 & -0.08 & 2.25 & 0.33 & 1.68 & 0.36 & 1.04 & -0.56 & 5.04 & -0.74 & 2.36 \\
\hline$\% \Delta$ AUDTWI & 0.04 & 2.13 & -0.41 & 2.10 & -0.07 & 1.99 & 0.29 & 1.50 & 0.06 & 1.52 & 0.01 & 3.45 & 0.03 & 1.70 \\
\hline$\Delta$ YieldCurve & 0.00 & 0.20 & -0.03 & 0.15 & 0.01 & 0.20 & -0.01 & 0.19 & -0.01 & 0.13 & 0.02 & 0.29 & 0.02 & 0.19 \\
\hline Number of obs. & \multicolumn{2}{|c|}{407} & \multicolumn{2}{|c|}{21} & \multicolumn{2}{|c|}{78} & \multicolumn{2}{|c|}{74} & \multicolumn{2}{|c|}{79} & \multicolumn{2}{|c|}{74} & \multicolumn{2}{|c|}{81} \\
\hline Election Result & & & \multicolumn{2}{|c|}{$\begin{array}{c}\text { LNP - } 80 \text { seats } \\
(49.02 \%)\end{array}$} & \multicolumn{2}{|c|}{$\begin{array}{c}\text { LNP - } 82 \text { seats } \\
(50.95 \%)\end{array}$} & \multicolumn{2}{|c|}{$\begin{array}{c}\text { LNP - } 87 \text { seats } \\
(52.74 \%)\end{array}$} & \multicolumn{2}{|c|}{$\begin{array}{c}\text { ALP - } 83 \text { seats } \\
(52.70 \%)\end{array}$} & \multicolumn{2}{|c|}{$\begin{array}{c}\text { ALP - } 72 \text { seats } \\
(50.12 \%)\end{array}$} & \multicolumn{2}{|c|}{$\begin{array}{c}\text { LNP - } 90 \text { seats } \\
(53.49 \%)\end{array}$} \\
\hline Panel B: Election & \multicolumn{2}{|c|}{ Overall } & \multicolumn{2}{|c|}{1998 Election } & \multicolumn{2}{|c|}{2001 Election } & \multicolumn{2}{|c|}{2004 Election } & \multicolumn{2}{|c|}{2007 Election } & \multicolumn{2}{|c|}{2010 Election } & \multicolumn{2}{|c|}{2013 Election } \\
\hline Year Only & Mean & Std Dev & Mean & Std Dev & Mean & Std Dev & Mean & Std Dev & Mean & Std Dev & Mean & Std Dev & Mean & Std Dev \\
\hline$\% \Delta \sigma_{\mathrm{SPX}}$ & -0.12 & 14.72 & -0.04 & 11.55 & 0.10 & 22.97 & -0.44 & 11.43 & 2.13 & 12.67 & -0.30 & 10.61 & -2.06 & 16.10 \\
\hline$\% \Delta \sigma_{10 \mathrm{YB}}$ & 0.19 & 9.08 & -0.09 & 20.52 & 0.60 & 4.76 & -0.94 & 3.90 & 1.62 & 7.29 & -0.30 & 6.44 & 0.22 & 8.00 \\
\hline$\% \Delta \sigma_{\text {AUD }}$ & 0.52 & 7.21 & 1.71 & 4.00 & -0.16 & 6.72 & -0.03 & 3.88 & 2.25 & 8.38 & -0.57 & 8.83 & 0.32 & 8.79 \\
\hline$\% \Delta \mathrm{EU}$ & 0.11 & 5.18 & 0.34 & 4.52 & 0.41 & 5.84 & -0.03 & 3.34 & -0.02 & 6.92 & 0.27 & 5.81 & -0.22 & 4.10 \\
\hline Number of obs. & & 177 & & & & & 3 & 2 & 3 & 1 & & & 3 & \\
\hline
\end{tabular}

Note: This table presents summary statistics for the data used in the empirical analysis of this paper. Panel A reports statistics for the whole sample period, while Panel B reports statistics for the variables of interest in the period covering the year prior to the election. Variables include the percentage change of implied volatility of SPX equity options, 10 -yr government bond options, and AUD-USD options traded on the ASX. In addition, the percentage change in measure political uncertainty (EU) and a range of macroeconomic control variables including VIX, inflation, unemployment, consumer confidence, economic growth, the $3 \mathrm{~m}$ treasury-bill interest rate, the yield curve, and the AUD tradeweighted index are included. 
TABLE 2

Correlations for implied volatility, political and macroeconomic variables

\begin{tabular}{|c|c|c|c|c|c|c|c|c|c|c|c|c|}
\hline & $\% \Delta \sigma_{\mathrm{SPX}}$ & $\% \Delta \sigma_{10 \text { Yв }}$ & $\% \Delta \sigma_{\text {AUD }}$ & $\% \Delta \mathrm{EU}$ & $\% \Delta \mathrm{VIX}$ & $\% \Delta I N F L$ & $\% \Delta \mathrm{UNEMP}$ & $\% \Delta \mathrm{GDP}$ & $\% \Delta \mathrm{ASX}$ & $\% \Delta \mathrm{CONSCONF}$ & $\% \Delta 3 \mathrm{MTB}$ & $\% \Delta$ AUDTWI \\
\hline$\% \Delta \sigma_{10 \mathrm{YB}}$ & 0.127 & & & & & & & & & & & \\
\hline$\% \Delta \sigma_{\mathrm{AUD}}$ & 0.384 & 0.097 & & & & & & & & & & \\
\hline$\% \Delta \mathrm{EU}$ & 0.179 & 0.117 & 0.162 & & & & & & & & & \\
\hline$\% \Delta$ VIX & 0.480 & 0.101 & 0.444 & 0.134 & & & & & & & & \\
\hline$\% \Delta \mathrm{INFL}$ & 0.042 & -0.036 & 0.036 & 0.003 & 0.027 & & & & & & & \\
\hline$\% \Delta U N E M P$ & 0.079 & 0.040 & 0.055 & 0.023 & 0.022 & -0.083 & & & & & & \\
\hline$\% \Delta \mathrm{GDP}$ & 0.063 & 0.055 & 0.058 & 0.052 & 0.068 & -0.096 & -0.032 & & & & & \\
\hline$\% \Delta \mathrm{ASX}$ & -0.664 & -0.147 & -0.434 & -0.110 & -0.528 & -0.104 & -0.090 & -0.027 & & & & \\
\hline$\% \Delta \mathrm{CONSCONF}$ & -0.095 & -0.051 & -0.135 & 0.034 & -0.068 & -0.099 & 0.045 & 0.063 & 0.146 & & & \\
\hline$\% \Delta 3 \mathrm{MTB}$ & -0.031 & 0.044 & -0.092 & -0.052 & 0.035 & 0.019 & -0.014 & 0.165 & 0.069 & 0.064 & & \\
\hline$\% \Delta$ AUDTWI & -0.322 & -0.151 & -0.516 & -0.064 & -0.354 & -0.049 & -0.011 & -0.013 & 0.479 & 0.115 & 0.274 & \\
\hline$\Delta$ YieldCurve & -0.055 & 0.036 & -0.043 & 0.030 & -0.237 & -0.089 & 0.063 & -0.087 & 0.205 & 0.022 & -0.388 & 0.068 \\
\hline
\end{tabular}

Note: This table reports the cross-correlations for the variables included within the empirical analysis of this paper. Variables include the percentage change of implied volatility of SPX equity options, 10-yr government bond options, and AUD-USD options traded on the ASX. In addition, the percentage change in measure political uncertainty $(E U)$ and a range of macroeconomic control variables including VIX, inflation, unemployment, consumer confidence, economic growth, the $3 \mathrm{~m}$ treasury-bill interest rate, the yield curve, and the AUD trade-weighted index are included. The entire sample of 407 observations is used to calculate the correlations, and estimates displayed in bold are significant at the $5 \%$ level. 
TABLE 3

Base regression: Influence of political uncertainty on market uncertainty

\begin{tabular}{|c|c|c|c|c|c|c|c|c|c|}
\hline \multirow{2}{*}{$\begin{array}{l}\text { Variable } \\
\text { Constant }\end{array}$} & \multicolumn{3}{|c|}{$\% \Delta \sigma_{S P X}$} & \multicolumn{3}{|c|}{$\% \Delta \sigma_{10 Y B}$} & \multicolumn{3}{|c|}{$\% \Delta \sigma_{A U D}$} \\
\hline & $\begin{array}{l}-0.227 \\
(0.707)\end{array}$ & $\begin{array}{l}-0.286 \\
(0.702)\end{array}$ & $\begin{array}{l}-0.266 \\
(0.705)\end{array}$ & $\begin{array}{l}0.093 \\
(0.443)\end{array}$ & $\begin{array}{c}0.079 \\
(0.443)\end{array}$ & $\begin{array}{l}0.058 \\
(0.444)\end{array}$ & $\begin{array}{c}0.074 \\
(0.379)\end{array}$ & $\begin{array}{c}0.055 \\
(0.378)\end{array}$ & $\begin{array}{c}0.053 \\
(0.370)\end{array}$ \\
\hline$\% \triangle E U$ & $\begin{array}{l}0.515^{* * *} \\
(0.149)\end{array}$ & $\begin{array}{c}0.153 \\
(0.196)\end{array}$ & $\begin{array}{c}0.247 \\
(0.353)\end{array}$ & $\begin{array}{c}0.275^{* * *} \\
(0.094)\end{array}$ & $\begin{array}{c}0.195 \\
(0.124)\end{array}$ & $\begin{array}{c}0.261 \\
(0.223)\end{array}$ & $\begin{array}{l}0.228^{* * *} \\
(0.079)\end{array}$ & $\begin{array}{c}0.051 \\
(0.120)\end{array}$ & $\begin{array}{c}0.210 \\
(0.216)\end{array}$ \\
\hline $\begin{array}{l}\% \Delta E U^{*} \text { Election } \\
\text { Year }\end{array}$ & & $\begin{array}{c}0.837^{* * *} \\
(0.298)\end{array}$ & & & $\begin{array}{l}0.285^{* *} \\
(0.138)\end{array}$ & & & $\begin{array}{l}0.364^{* *} \\
(0.177)\end{array}$ & \\
\hline$\% \triangle E U^{*} D S L E$ & & & $\begin{array}{l}0.001^{* *} \\
(0.000)\end{array}$ & & & $\begin{array}{l}0.002^{* *} \\
(0.001)\end{array}$ & & & $\begin{array}{l}0.001^{* *} \\
(0.000)\end{array}$ \\
\hline$A R(1)$ & $\begin{array}{l}-0.096^{*} \\
(0.050)\end{array}$ & $\begin{array}{l}-0.089^{*} \\
(0.049)\end{array}$ & $\begin{array}{l}-0.095^{*} \\
(0.050)\end{array}$ & $\begin{array}{c}-0.209^{* * *} \\
(0.051)\end{array}$ & $\begin{array}{c}-0.207^{* * *} \\
(0.051)\end{array}$ & $\begin{array}{c}-0.208^{* * *} \\
(0.051)\end{array}$ & $\begin{array}{l}-0.008 \\
(0.051)\end{array}$ & $\begin{array}{l}-0.022 \\
(0.057)\end{array}$ & $\begin{array}{l}-0.018 \\
(0.057)\end{array}$ \\
\hline Adj. $R^{2}$ & 0.212 & 0.238 & 0.241 & 0.060 & 0.063 & 0.058 & 0.042 & 0.053 & 0.052 \\
\hline F-Stat & 7.754 & 7.914 & 7.017 & 12.251 & 8.495 & 7.848 & 4.173 & 3.676 & 3.278 \\
\hline No. Obs & 386 & 386 & 386 & 386 & 386 & 386 & 386 & 386 & 386 \\
\hline
\end{tabular}

Note: This table presents results from the base regression set out in Eq. (2) whereby the percentage change in implied volatility of SPX equity options, 10-yr bond options, and AUD/USD currency options are regressed on the percentage change in the identified political uncertainty variable (and Election Uncertainty, EU) as well as an interaction term indicating proximity to the election date( Election Year takes a value of 1 if the observation occurs during election year and 0 otherwise; Days since last election ( DSLE) indicates days since the last election day), and one-lagged term of the dependent variable. Based on a Hausman Test, a random effects panel specification is used to model the overall effect. Robust standard errors reported in parentheses. ${ }^{* * *},{ }^{* *},{ }^{*}$ denote significance at the $1 \%, 5 \%$, and $10 \%$ levels respectively. 
Table 4

Base regression: Influence of political uncertainty on market uncertainty for individual election cycles

\begin{tabular}{|c|c|c|c|c|c|c|c|c|c|c|c|}
\hline \multirow{2}{*}{$\frac{\text { Panel } A}{\text { Variable }}$} & \multicolumn{11}{|c|}{$\% \Delta \sigma_{S P X}$} \\
\hline & 1998 & 2001 & 2001 & 2004 & 2004 & 2007 & 2007 & 2010 & 2010 & 2013 & 2013 \\
\hline \multirow[t]{2}{*}{ Constant } & 0.072 & -1.477 & -1.669 & -0.172 & -0.187 & 1.256 & 1.268 & -0.326 & -0.386 & -1.257 & -0.938 \\
\hline & (2.421) & (2.068) & (2.063) & (1.451) & (1.462) & (1.485) & (1.496) & (1.645) & (1.642) & (1.539) & (1.493) \\
\hline \multirow[t]{2}{*}{$\% \Delta E U$} & $1.320^{* *}$ & $0.952^{* *}$ & 0.483 & 0.606 & 0.536 & 0.391 & 0.452 & 0.119 & -0.133 & 0.548 & 0.068 \\
\hline & $(0.547)$ & $(0.404)$ & $(0.539)$ & $(0.406)$ & $(0.482)$ & $(0.282)$ & $(0.440)$ & (0.308) & $(0.378)$ & $(0.345)$ & $(0.384)$ \\
\hline \multirow{2}{*}{$\begin{array}{l}\% \Delta E U^{*} \text { Election } \\
\text { Year }\end{array}$} & & & $1.052^{* *}$ & & $0.249^{* *}$ & & 0.105 & & $0.744^{* *}$ & & $1.991^{* *}$ \\
\hline & & & $(0.405)$ & & $(0.123)$ & & $(0.578)$ & & $(0.365)$ & & $(0.788)$ \\
\hline \multirow[t]{2}{*}{$A R(1)$} & -0.011 & -0.031 & -0.041 & -0.125 & -0.123 & -0.187 & -0.187 & -0.072 & -0.058 & $-0.198^{*}$ & -0.141 \\
\hline & $(0.218)$ & $(0.112)$ & $(0.112)$ & $(0.121)$ & $(0.123)$ & $(0.116)$ & $(0.117)$ & (0.119) & $(0.119)$ & $(0.112)$ & $(0.111)$ \\
\hline Adj. $R^{2}$ & 0.266 & 0.073 & 0.096 & 0.047 & 0.048 & 0.059 & 0.059 & 0.007 & 0.026 & 0.073 & 0.146 \\
\hline F-Stat & 2.911 & 2.780 & 2.439 & 1.687 & 2.134 & 1.902 & 1.483 & 1.254 & 2.604 & 2.995 & 4.262 \\
\hline No. Obs & 19 & 73 & 73 & 71 & 71 & 75 & 75 & 72 & 72 & 79 & 79 \\
\hline \multicolumn{6}{|l|}{ Panel B } & \multicolumn{6}{|l|}{$\% \Delta \sigma_{10 Y B}$} \\
\hline Variable & 1998 & 2001 & 2001 & 2004 & 2004 & 2007 & 2007 & 2010 & 2010 & 2013 & 2013 \\
\hline \multirow[t]{2}{*}{ Constant } & 2.652 & -0.431 & -0.508 & -0.206 & -0.243 & 0.048 & 0.032 & 0.420 & 0.374 & 0.373 & 0.407 \\
\hline & (4.498) & $(0.682)$ & $(0.672)$ & (0.358) & $(0.350)$ & $(0.671)$ & $(0.673)$ & (1.356) & (1.356) & $(1.051)$ & (1.058) \\
\hline \multirow[t]{2}{*}{$\% \Delta E U$} & $1.031^{* *}$ & $0.337^{* *}$ & 0.125 & 0.136 & 0.011 & $0.382^{* * *}$ & 0.271 & 0.261 & 0.074 & $0.403^{*}$ & 0.331 \\
\hline & $(1.046)$ & $(0.132)$ & $(0.176)$ & $(0.101)$ & $(0.116)$ & $(0.130)$ & $(0.200)$ & (0.259) & $(0.315)$ & $(0.236)$ & $(0.274)$ \\
\hline \multirow{2}{*}{$\begin{array}{l}\% \Delta E U^{*} \text { Election } \\
\text { Year }\end{array}$} & & & $0.473^{* *}$ & & $0.452^{* *}$ & & 0.191 & & $0.554^{* *}$ & & 0.289 \\
\hline & & & $(0.226)$ & & $(0.220)$ & & $(0.262)$ & & $(0.253)$ & & $(0.551)$ \\
\hline \multirow[t]{2}{*}{$A R(1)$} & $-0.474^{*}$ & -0.147 & -0.134 & 0.111 & 0.091 & -0.134 & -0.129 & -0.067 & -0.066 & -0.181 & -0.178 \\
\hline & $(0.245)$ & $(0.111)$ & $(0.110)$ & $(0.120)$ & $(0.118)$ & $(0.111)$ & $(0.112)$ & $(0.118)$ & $(0.118)$ & $(0.111)$ & $(0.112)$ \\
\hline Adj. $R^{2}$ & 0.179 & 0.109 & 0.112 & 0.040 & 0.097 & 0.138 & 0.144 & 0.017 & 0.031 & 0.066 & 0.069 \\
\hline F-Stat & 2.964 & 4.273 & 4.019 & 1.434 & 2.400 & 5.760 & 3.990 & 1.579 & 2.745 & 2.681 & 1.860 \\
\hline No. Obs & 19 & 73 & 73 & 71 & 71 & 75 & 75 & 72 & 72 & 79 & 79 \\
\hline \multicolumn{6}{|l|}{ Panel C } & \multicolumn{6}{|l|}{$\% \Delta \sigma_{A \cup D}$} \\
\hline Variable & 1998 & 2001 & 2001 & 2004 & 2004 & 2007 & 2007 & 2010 & 2010 & 2013 & 2013 \\
\hline \multirow[t]{2}{*}{ Constant } & 1.745 & -0.397 & -0.454 & -0.326 & -0.314 & 0.540 & 0.521 & 0.185 & 0.164 & -0.083 & 0.018 \\
\hline & -1.069 & $(0.789)$ & $(0.792)$ & $(0.492)$ & $(0.496)$ & $(0.753)$ & $(0.756)$ & (1.241) & $(1.248)$ & $(0.961)$ & $(0.951)$ \\
\hline \multirow[t]{2}{*}{$\% \Delta E U$} & 0.052 & 0.133 & 0.002 & 0.186 & 0.227 & $0.287^{*}$ & 0.155 & 0.324 & 0.237 & 0.304 & 0.095 \\
\hline & -0.232 & $(0.154)$ & $(0.207)$ & $(0.141)$ & $(0.168)$ & $(0.154)$ & $(0.231)$ & $(0.233)$ & $(0.287)$ & $(0.216)$ & $(0.246)$ \\
\hline \multirow{2}{*}{$\begin{array}{l}\% \Delta E U^{*} \text { Election } \\
\text { Year }\end{array}$} & & & $0.298^{* *}$ & & 0.142 & & 0.224 & & $0.257^{*}$ & & $0.845^{*}$ \\
\hline & & & $(0.134)$ & & $(0.312)$ & & $(0.293)$ & & $(0.143)$ & & $(0.496)$ \\
\hline \multirow[t]{2}{*}{$A R(1)$} & -0.178 & -0.110 & -0.133 & 0.056 & 0.061 & 0.004 & 0.001 & 0.016 & 0.015 & 0.009 & 0.024 \\
\hline & -0.256 & $(0.119)$ & $(0.121)$ & $(0.112)$ & $(0.113)$ & $(0.124)$ & $(0.293)$ & (0.119) & $(0.120)$ & $(0.114)$ & $(0.113)$ \\
\hline Adj. $R^{2}$ & 0.029 & 0.020 & 0.033 & 0.026 & 0.048 & 0.052 & 0.059 & 0.027 & 0.036 & 0.025 & 0.062 \\
\hline F-Stat & 2.42 & 2.727 & 2.783 & 2.890 & 2.134 & 1.956 & 1.491 & 1.972 & 2.604 & 1.993 & 1.644 \\
\hline No. Obs & 19 & 73 & 73 & 71 & 71 & 75 & 75 & 72 & 72 & 79 & 79 \\
\hline
\end{tabular}

Note: 'I'his table presents results trom the base regression set out in Eq. (2) whereby the percentage change in implied volatility of SPX equity options, 10-yr bond options, and AUD/USD currency options are regressed on the percentage change in the identified political uncertainty variable (and Election Uncertainty, EU) as well as an interaction term indicating there is less than 1-year remaining to the maximum allowed 3-year term (Election Year), an interaction term indicating the number of days since the last election (DSLE), and one-lagged term of the dependent variable. A simple linear OLS is used to disaggregate into individual election cycles. Robust standard errors reported in parentheses.

${ }^{* * *},{ }^{* *},{ }^{*}$ denote significance at the $1 \%, 5 \%$, and $10 \%$ levels respectively. 
TABLE 5

Regression: The influence of macroeconomic variables and political uncertainty on implied volatility

\begin{tabular}{|c|c|c|c|c|c|c|c|c|c|}
\hline \multirow[b]{2}{*}{ Variable } & \multicolumn{3}{|c|}{$\% \Delta \sigma_{S P X}$} & \multicolumn{3}{|c|}{$\% \Delta \sigma_{10 Y B}$} & \multicolumn{3}{|c|}{$\% \Delta \sigma_{A U D}$} \\
\hline & Model 1 & Model 2 & Model 3 & Model 1 & Model 2 & Model 3 & Model 1 & Model 2 & Model 3 \\
\hline \multirow{2}{*}{ Constant } & 0.221 & 0.182 & 0.193 & 0.212 & 0.204 & 0.215 & 0.128 & 0.119 & 0.123 \\
\hline & $(0.539)$ & $(0.533)$ & $(0.532)$ & $(0.444)$ & $(0.443)$ & $(0.444)$ & $(0.305)$ & $(0.304)$ & $(0.304)$ \\
\hline \multirow[t]{2}{*}{$\% \Delta E U$} & $0.287^{* *}$ & 0.049 & 0.241 & $0.237^{* *}$ & 0.186 & 0.279 & $0.128^{* *}$ & 0.079 & 0.023 \\
\hline & $(0.114)$ & $(0.148)$ & $(0.265)$ & $(0.093)$ & $(0.123)$ & $(0.221)$ & $(0.064)$ & $(0.085)$ & $(0.152)$ \\
\hline \multirow{2}{*}{$\begin{array}{l}\% \Delta E U^{*} \text { Election } \\
\text { Year }\end{array}$} & & $0.560^{* *}$ & & & $0.118^{* *}$ & & & $0.115^{* *}$ & \\
\hline & & $(0.226)$ & & & $(0.058)$ & & & $(0.049)$ & \\
\hline \multirow[t]{2}{*}{$\% \Delta E U^{*} D S L E$} & & & $0.002^{* *}$ & & & $0.006^{* *}$ & & & $0.004^{* *}$ \\
\hline & & & $(0.001)$ & & & $(0.003)$ & & & $(0.002)$ \\
\hline \multirow[t]{2}{*}{$\Delta$ Deficit } & 0.001 & $0.001^{*}$ & $0.001^{*}$ & 0.006 & 0.001 & 0.002 & 0.008 & 0.008 & 0.008 \\
\hline & $(0.001)$ & $(0.000)$ & $(0.000)$ & $(0.009)$ & $(0.001)$ & $(0.008)$ & $(0.006)$ & $(0.006)$ & $(0.006)$ \\
\hline \multirow[t]{2}{*}{$\% \Delta V I X$} & $0.159^{* * *}$ & $0.149^{* * *}$ & $0.152^{* * *}$ & 0.014 & 0.013 & 0.015 & $0.118^{* * *}$ & $0.116^{* * *}$ & $0.117^{* * *}$ \\
\hline & $(0.043)$ & $(0.043)$ & $(0.042)$ & $(0.036)$ & $(0.035)$ & $(0.035)$ & $(0.024)$ & $(0.024)$ & $(0.024)$ \\
\hline \multirow[t]{2}{*}{$\% \triangle I N F L$} & 1.232 & 1.150 & 1.109 & $0.932^{*}$ & $0.912^{*}$ & $0.943^{*}$ & 0.609 & 0.593 & 0.585 \\
\hline & $(0.817)$ & $(0.807)$ & $(0.807)$ & $(0.543)$ & $(0.536)$ & $(0.536)$ & $(0.462)$ & $(0.462)$ & $(0.462)$ \\
\hline \multirow[t]{2}{*}{$\% \triangle U N E M P$} & 0.139 & 0.124 & 0.135 & 0.074 & 0.071 & 0.074 & -0.051 & -0.054 & -0.052 \\
\hline & $(0.191)$ & $(0.189)$ & $(0.189)$ & $(0.156)$ & $(0.157)$ & $(0.156)$ & $(0.108)$ & $(0.108)$ & $(0.108)$ \\
\hline \multirow[t]{2}{*}{$\% \triangle G D P$} & 0.477 & 0.549 & 0.532 & 0.313 & 0.329 & 0.308 & 0.366 & 0.382 & 0.377 \\
\hline & $(0.665)$ & $(0.652)$ & $(0.655)$ & $(0.544)$ & $(0.545)$ & $(0.544)$ & $(0.376)$ & $(0.376)$ & $(0.375)$ \\
\hline \multirow[t]{2}{*}{$\% \triangle A S X$} & $-2.643^{* * *}$ & $-2.649^{* * *}$ & $-2.648^{* * *}$ & -0.135 & -0.136 & -0.135 & $-0.342^{* * *}$ & $-0.343^{* * *}$ & $-0.344^{* * *}$ \\
\hline & $(0.223)$ & $(0.219)$ & $(0.219)$ & $(0.182)$ & $(0.182)$ & $(0.182)$ & $(0.126)$ & $(0.126)$ & $(0.126)$ \\
\hline \multirow[t]{2}{*}{$\% \triangle C O N S C O N F$} & -0.089 & -0.087 & -0.090 & -0.119 & -0.119 & -0.120 & $-0.106^{*}$ & $-0.107^{*}$ & $-0.107^{*}$ \\
\hline & $(0.101)$ & $(0.099)$ & $(0.098)$ & $(0.082)$ & $(0.082)$ & $(0.081)$ & $(0.057)$ & $(0.057)$ & $(0.057)$ \\
\hline \multirow[t]{2}{*}{$\% \triangle 3 M T B$} & 0.238 & 0.244 & 0.242 & $0.394^{* *}$ & $0.396^{* *}$ & $0.393^{* *}$ & 0.127 & 0.128 & 0.128 \\
\hline & $(0.217)$ & $(0.214)$ & $(0.213)$ & $(0.177)$ & $(0.178)$ & $(0.177)$ & $(0.122)$ & $(0.121)$ & $(0.122)$ \\
\hline \multirow[t]{2}{*}{$\% \triangle A U D T W I$} & -0.062 & -0.063 & -0.064 & $-0.708^{* * *}$ & $-0.709^{* * *}$ & $-0.707^{* * *}$ & $-1.369^{* * *}$ & $-1.371^{* * *}$ & $-1.370^{* * *}$ \\
\hline & $(0.305)$ & $(0.301)$ & $(0.301)$ & $(0.249)$ & $(0.249)$ & $(0.249)$ & $(0.172)$ & $(0.172)$ & $(0.171)$ \\
\hline \multirow[t]{2}{*}{$\Delta$ YieldCurve } & $7.069^{* *}$ & $7.159^{* *}$ & $7.384^{* *}$ & 3.451 & 3.479 & 3.423 & 2.521 & 2.541 & 2.584 \\
\hline & (3.029) & $(2.988)$ & $(2.984)$ & (2.478) & (2.481) & $(2.481)$ & (1.711) & (1.709) & (1.707) \\
\hline \multirow[t]{2}{*}{$A R(1)$} & $-0.089^{* *}$ & $-0.084^{* *}$ & $-0.088^{* *}$ & $-0.219^{* * *}$ & $-0.219^{* * *}$ & $-0.220^{* * *}$ & -0.028 & -0.029 & -0.028 \\
\hline & $(0.038)$ & $(0.038)$ & $(0.038)$ & $(0.050)$ & $(0.050)$ & $(0.050)$ & $(0.041)$ & $(0.041)$ & $(0.040)$ \\
\hline Adj. $R^{2}$ & 0.507 & 0.516 & 0.514 & 0.115 & 0.116 & 0.114 & 0.412 & 0.414 & 0.413 \\
\hline F-Stat & 31.886 & 30.372 & 30.153 & 4.010 & 3.729 & 3.695 & 21.752 & 20.132 & 20.103 \\
\hline No. Obs & 386 & 386 & 386 & 386 & 386 & 386 & 386 & 386 & 386 \\
\hline
\end{tabular}

Note: This table presents results from the regression set out in Eq. (3) whereby the percentage change in implied volatility of SPX equity options, 10yr bond options, and AUD/USD currency options are regressed on the percentage change in the identified political uncertainty variable (Election Uncertainty, $E U$ ), an interaction term indicating there is less than 1-year remaining to the maximum allowed 3-year term (Election Year), an interaction term indicating the number of days since the last election (DSLE), one-lagged term of the dependent variable, and on a number of control variables for macroeconomic variables. Economic variables are the change in the fiscal deficit (Deficit), percentage change in the CBOE Volatility Index $(V I X)$, percentage change in inflation (INFL), unemployment (UNEMP), gross domestic product (GDP), the stock market $(A S X)$, the yield on 3-month Treasury bills (3MTB), consumer confidence (CONSCONF), and A $\$$ trade weighted index (AUDTWI). The change in the level of the yield curve slope measure by the difference between 10-yr government bond and 3-month Treasury bill yields is also included (YieldCurve). Robust standard errors in parentheses.

${ }^{* * *},{ }^{* *},{ }^{*}$ denote significance at the $1 \%, 5 \%$, and $10 \%$ levels respectively. 
TABLE 6

Regression: Influence of political uncertainty on market uncertainty by industry

\begin{tabular}{|c|c|c|c|c|c|c|c|c|c|c|}
\hline $\begin{array}{l}\text { Panel A } \\
\text { Industry }\end{array}$ & Utilities & $\begin{array}{c}\text { Basic } \\
\text { Materials }\end{array}$ & $\begin{array}{l}\text { Consumer } \\
\text { Goods }\end{array}$ & $\begin{array}{c}\text { Consumer } \\
\text { Services }\end{array}$ & Financials & $\begin{array}{l}\text { Health } \\
\text { Care }\end{array}$ & Industrials & Energy & Technology & Telecoms \\
\hline Constant & $\begin{array}{l}-0.499 \\
(0.823)\end{array}$ & $\begin{array}{l}-0.061 \\
(0.602)\end{array}$ & $\begin{array}{c}0.267 \\
(0.723)\end{array}$ & $\begin{array}{c}0.154 \\
(0.536)\end{array}$ & $\begin{array}{l}-0.246 \\
(0.497)\end{array}$ & $\begin{array}{c}0.504 \\
(0.673)\end{array}$ & $\begin{array}{c}0.160 \\
(0.550)\end{array}$ & $\begin{array}{c}0.129 \\
(0.666)\end{array}$ & $\begin{array}{c}0.643 \\
(1.100)\end{array}$ & $\begin{array}{l}-0.348 \\
(0.850)\end{array}$ \\
\hline$\% \triangle E U$ & $\begin{array}{c}0.067 \\
(0.230)\end{array}$ & $\begin{array}{l}0.449^{* * *} \\
(0.169)\end{array}$ & $\begin{array}{c}0.074 \\
(0.202)\end{array}$ & $\begin{array}{c}0.188 \\
(0.150)\end{array}$ & $\begin{array}{c}0.154 \\
(0.139)\end{array}$ & $\begin{array}{l}-0.066 \\
(0.188)\end{array}$ & $\begin{array}{c}0.055 \\
(0.154)\end{array}$ & $\begin{array}{c}0.086 \\
(0.186)\end{array}$ & $\begin{array}{c}0.378 \\
(0.306)\end{array}$ & $\begin{array}{c}0.005 \\
(0.238)\end{array}$ \\
\hline $\begin{array}{l}\% \Delta E U^{*} \text { Election } \\
\text { Year }\end{array}$ & -0.024 & 0.307 & 0.226 & -0.135 & 0.183 & 0.257 & 0.249 & 0.051 & 0.210 & 0.546 \\
\hline$A R(1)$ & $\begin{array}{c}(0.350) \\
-0.034 \\
(0.050)\end{array}$ & $\begin{array}{c}(0.256) \\
0.046 \\
(0.051)\end{array}$ & $\begin{array}{c}(0.308) \\
0.140^{* * *} \\
(0.050)\end{array}$ & $\begin{array}{c}(0.228) \\
0.185^{* * *} \\
(0.048)\end{array}$ & $\begin{array}{c}(0.211) \\
0.278^{* * *} \\
(0.048)\end{array}$ & $\begin{array}{l}(0.286) \\
-0.002 \\
(0.050)\end{array}$ & $\begin{array}{c}(0.234) \\
0.197^{* * *} \\
(0.048)\end{array}$ & $\begin{array}{l}(0.283) \\
0.131^{* *} \\
(0.051)\end{array}$ & $\begin{array}{c}(0.466) \\
0.011 \\
(0.049)\end{array}$ & $\begin{array}{c}(0.362) \\
0.063 \\
(0.049)\end{array}$ \\
\hline $\begin{array}{l}\text { Adj. } R^{2} \\
\text { F-Stat } \\
\text { No. Obs }\end{array}$ & $\begin{array}{c}0.001 \\
0.188 \\
386 \\
\end{array}$ & $\begin{array}{c}0.023 \\
2.990 \\
386 \\
\end{array}$ & $\begin{array}{c}0.024 \\
3.111 \\
386 \\
\end{array}$ & $\begin{array}{c}0.040 \\
5.302 \\
386 \\
\end{array}$ & $\begin{array}{c}0.092 \\
12.872 \\
386 \\
\end{array}$ & $\begin{array}{c}0.002 \\
0.308 \\
386 \\
\end{array}$ & $\begin{array}{c}0.049 \\
6.493 \\
386 \\
\end{array}$ & $\begin{array}{c}0.018 \\
2.374 \\
386 \\
\end{array}$ & $\begin{array}{c}0.011 \\
1.478 \\
386 \\
\end{array}$ & $\begin{array}{c}0.015 \\
1.910 \\
386 \\
\end{array}$ \\
\hline $\begin{array}{l}\text { Panel B } \\
\text { Industry }\end{array}$ & Utilities & $\begin{array}{c}\text { Basic } \\
\text { Materials } \\
\end{array}$ & $\begin{array}{c}\text { Consumer } \\
\text { Goods }\end{array}$ & $\begin{array}{c}\text { Consumer } \\
\text { Services } \\
\end{array}$ & Financials & $\begin{array}{c}\text { Health } \\
\text { Care }\end{array}$ & Industrials & Energy & Technology & Telecoms \\
\hline Constant & $\begin{array}{l}-0.422 \\
(0.822)\end{array}$ & $\begin{array}{l}-0.139 \\
(0.589)\end{array}$ & $\begin{array}{c}0.321 \\
(0.711)\end{array}$ & $\begin{array}{c}0.243 \\
(0.524)\end{array}$ & $\begin{array}{l}-0.088 \\
(0.463)\end{array}$ & $\begin{array}{c}0.609 \\
(0.667)\end{array}$ & $\begin{array}{c}0.223 \\
(0.525)\end{array}$ & $\begin{array}{c}0.151 \\
(0.667)\end{array}$ & $\begin{array}{c}0.652 \\
(1.107)\end{array}$ & $\begin{array}{l}-0.280 \\
(0.832)\end{array}$ \\
\hline$\% \triangle E U$ & $\begin{array}{c}0.048 \\
(0.228)\end{array}$ & $\begin{array}{l}0.453^{* * *} \\
(0.164)\end{array}$ & $\begin{array}{l}0.090 \\
(0.197)\end{array}$ & $\begin{array}{c}0.173 \\
(0.145)\end{array}$ & $\begin{array}{c}0.135 \\
(0.128)\end{array}$ & $\begin{array}{l}-0.083 \\
(0.185)\end{array}$ & $\begin{array}{c}0.065 \\
(0.146)\end{array}$ & $\begin{array}{c}0.078 \\
(0.185)\end{array}$ & $\begin{array}{c}0.389 \\
(0.307)\end{array}$ & $\begin{array}{c}0.029 \\
(0.231)\end{array}$ \\
\hline $\begin{array}{l}\% \Delta E U^{*} \text { Election } \\
\text { Year }\end{array}$ & -0.021 & $0.498^{* *}$ & -0.020 & -0.316 & -0.024 & 0.095 & 0.041 & 0.050 & 0.023 & 0.339 \\
\hline & (0.349) & $(0.251)$ & $(0.302)$ & $(0.222)$ & (0.196) & $(0.283)$ & $(0.223)$ & $(0.283)$ & $(0.469)$ & $(0.353)$ \\
\hline$\Delta$ Deficit & $\begin{array}{l}-0.001 \\
(0.015)\end{array}$ & $\begin{array}{l}0.023^{* *} \\
(0.011)\end{array}$ & $\begin{array}{c}0.037^{* * *} \\
(0.013)\end{array}$ & $\begin{array}{l}0.022^{* *} \\
(0.010)\end{array}$ & $\begin{array}{l}0.029^{* * *} \\
(0.009)\end{array}$ & $\begin{array}{c}0.012 \\
(0.013)\end{array}$ & $\begin{array}{c}0.036^{* * *} \\
(0.010)\end{array}$ & $\begin{array}{c}0.013 \\
(0.012)\end{array}$ & $\begin{array}{l}0.040^{*} \\
(0.021)\end{array}$ & $\begin{array}{c}0.018 \\
(0.015)\end{array}$ \\
\hline$\% \Delta V I X$ & $\begin{array}{l}0.134^{* *} \\
(0.066)\end{array}$ & $\begin{array}{l}0.136^{* * *} \\
(0.047)\end{array}$ & $\begin{array}{l}0.145^{* *} \\
(0.057)\end{array}$ & $\begin{array}{l}0.156^{* * *} \\
(0.042)\end{array}$ & $\begin{array}{l}0.174^{* * *} \\
(0.037)\end{array}$ & $\begin{array}{l}0.098^{*} \\
(0.053)\end{array}$ & $\begin{array}{l}0.179^{* * *} \\
(0.042)\end{array}$ & $\begin{array}{l}0.042^{*} \\
(0.024)\end{array}$ & $\begin{array}{l}0.138^{* *} \\
(0.068)\end{array}$ & $\begin{array}{l}0.170^{* *} \\
(0.067)\end{array}$ \\
\hline$\% \triangle I N F L$ & $\begin{array}{c}1.432 \\
(1.246)\end{array}$ & $\begin{array}{c}0.236 \\
(0.894)\end{array}$ & $\begin{array}{c}0.143 \\
(1.077)\end{array}$ & $\begin{array}{c}0.432 \\
(0.794)\end{array}$ & $\begin{array}{c}0.455 \\
(0.701)\end{array}$ & $\begin{array}{c}0.712 \\
(1.012)\end{array}$ & $\begin{array}{c}0.235 \\
(0.796)\end{array}$ & $\begin{array}{c}0.323 \\
(1.013)\end{array}$ & $\begin{array}{c}0.808 \\
(1.678)\end{array}$ & $\begin{array}{c}0.708 \\
(1.260)\end{array}$ \\
\hline$\% \triangle U N E M P$ & $\begin{array}{l}-0.044 \\
(0.291)\end{array}$ & $\begin{array}{c}0.020 \\
(0.209)\end{array}$ & $\begin{array}{c}0.188 \\
(0.252)\end{array}$ & $\begin{array}{c}0.173 \\
(0.186)\end{array}$ & $\begin{array}{c}0.152 \\
(0.165)\end{array}$ & $\begin{array}{c}0.181 \\
(0.236)\end{array}$ & $\begin{array}{l}-0.013 \\
(0.186)\end{array}$ & $\begin{array}{c}0.025 \\
(0.237)\end{array}$ & $\begin{array}{c}0.238 \\
(0.392)\end{array}$ & $\begin{array}{c}0.011 \\
(0.295)\end{array}$ \\
\hline$\% \triangle G D P$ & $\begin{array}{l}-0.143 \\
(1.014)\end{array}$ & $\begin{array}{l}-1.048 \\
(0.727)\end{array}$ & $\begin{array}{l}-0.515 \\
(0.876)\end{array}$ & $\begin{array}{c}0.372 \\
(0.647)\end{array}$ & $\begin{array}{c}0.131 \\
(0.571)\end{array}$ & $\begin{array}{c}0.306 \\
(0.822)\end{array}$ & $\begin{array}{l}-0.167 \\
(0.648)\end{array}$ & $\begin{array}{c}0.676 \\
(0.824)\end{array}$ & $\begin{array}{c}0.211 \\
(1.365)\end{array}$ & $\begin{array}{c}1.396 \\
(1.031)\end{array}$ \\
\hline$\% \triangle A S X$ & $\begin{array}{l}-0.386 \\
(0.338)\end{array}$ & $\begin{array}{l}-0.095 \\
(0.243)\end{array}$ & $\begin{array}{l}-0.042 \\
(0.293)\end{array}$ & $\begin{array}{l}-0.189 \\
(0.216)\end{array}$ & $\begin{array}{c}-0.435^{* *} \\
(0.190)\end{array}$ & $\begin{array}{l}-0.460^{*} \\
(0.275)\end{array}$ & $\begin{array}{l}-0.069 \\
(0.216)\end{array}$ & $\begin{array}{l}-0.215 \\
(0.275)\end{array}$ & $\begin{array}{l}-0.204 \\
(0.455)\end{array}$ & $\begin{array}{l}-0.340 \\
(0.343)\end{array}$ \\
\hline$\% \triangle C O N S C O N F$ & $\begin{array}{l}-0.202 \\
(0.152)\end{array}$ & $\begin{array}{l}-0.055 \\
(0.109)\end{array}$ & $\begin{array}{l}-0.074 \\
(0.132)\end{array}$ & $\begin{array}{l}-0.096 \\
(0.097)\end{array}$ & $\begin{array}{l}-0.120 \\
(0.087)\end{array}$ & $\begin{array}{l}-0.223^{*} \\
(0.124)\end{array}$ & $\begin{array}{l}-0.084 \\
(0.098)\end{array}$ & $\begin{array}{l}-0.024 \\
(0.125)\end{array}$ & $\begin{array}{c}0.258 \\
(0.204)\end{array}$ & $\begin{array}{l}-0.256^{*} \\
(0.154)\end{array}$ \\
\hline$\% \triangle 3 M T B$ & $\begin{array}{c}0.407 \\
(0.330)\end{array}$ & $\begin{array}{l}-0.232 \\
(0.237)\end{array}$ & $\begin{array}{c}0.003 \\
(0.285)\end{array}$ & $\begin{array}{l}-0.080 \\
(0.211)\end{array}$ & $\begin{array}{c}0.190 \\
(0.186)\end{array}$ & $\begin{array}{c}0.385 \\
(0.268)\end{array}$ & $\begin{array}{c}0.138 \\
(0.211)\end{array}$ & $\begin{array}{c}0.116 \\
(0.268)\end{array}$ & $\begin{array}{l}-0.601 \\
(0.445)\end{array}$ & $\begin{array}{c}0.258 \\
(0.354)\end{array}$ \\
\hline$\% \Delta A U D T W I$ & $\begin{array}{l}-0.261 \\
(0.466)\end{array}$ & $\begin{array}{l}-0.402 \\
(0.332)\end{array}$ & $\begin{array}{l}-0.552^{*} \\
(0.301)\end{array}$ & $\begin{array}{c}0.020 \\
(0.296)\end{array}$ & $\begin{array}{l}-0.114 \\
(0.263)\end{array}$ & $\begin{array}{l}-0.184 \\
(0.377)\end{array}$ & $\begin{array}{l}-0.495^{*} \\
(0.297)\end{array}$ & $\begin{array}{l}-0.626^{*} \\
(0.377)\end{array}$ & $\begin{array}{c}0.864 \\
(0.625)\end{array}$ & $\begin{array}{l}-0.776 \\
(0.569)\end{array}$ \\
\hline$\Delta$ YieldCurve & $\begin{array}{c}6.848 \\
(4.613)\end{array}$ & $\begin{array}{c}5.175 \\
(3.308)\end{array}$ & $\begin{array}{c}1.562 \\
(3.988)\end{array}$ & $\begin{array}{c}3.857 \\
(2.940)\end{array}$ & $\begin{array}{l}6.702^{* *} \\
(2.608)\end{array}$ & $\begin{array}{c}5.318 \\
(3.742)\end{array}$ & $\begin{array}{c}4.633 \\
(2.947)\end{array}$ & $\begin{array}{l}-3.358 \\
(3.743)\end{array}$ & $\begin{array}{l}-3.132 \\
(6.220)\end{array}$ & $\begin{array}{c}1.927 \\
(4.670)\end{array}$ \\
\hline$A R(1)$ & $\begin{array}{l}-0.042 \\
(0.049)\end{array}$ & $\begin{array}{c}0.036 \\
(0.049)\end{array}$ & $\begin{array}{l}0.124^{* *} \\
(0.049)\end{array}$ & $\begin{array}{l}0.157^{* * *} \\
(0.048)\end{array}$ & $\begin{array}{c}0.225 \\
(0.047)\end{array}$ & $\begin{array}{l}-0.021 \\
(0.049)\end{array}$ & $\begin{array}{l}0.155^{* * *} \\
(0.048)\end{array}$ & $\begin{array}{l}0.112^{* *} \\
(0.052)\end{array}$ & $\begin{array}{c}0.011 \\
(0.049)\end{array}$ & $\begin{array}{c}0.071 \\
(0.048)\end{array}$ \\
\hline Adj. $\mathrm{R}^{2}$ & 0.046 & 0.149 & 0.088 & 0.120 & 0.239 & 0.062 & 0.167 & 0.058 & 0.039 & 0.099 \\
\hline F-Stat & 1.396 & 3.256 & 2.744 & 3.902 & 8.990 & 1.886 & 5.717 & 1.768 & 1.159 & 3.156 \\
\hline No. Obs & 386 & 386 & 386 & 386 & 386 & 386 & 386 & 386 & 386 & 386 \\
\hline
\end{tabular}

Note: This table presents results from the regression specifiction whereby the percentage change in realized volatility of stocks, classified into 10 GICS sectors are regressed on the percentage change in the identified political uncertainty variable (Election Uncertainty, EU), one-lagged term of the dependent variable, and on a number of control variables for macroeconomic variables. Economic variables are the change in the fiscal deficit (Deficit), percentage change in the CBOE volatility index ( VIX), percentage change in inflation (INFL), unemployment (UNEMP), gross domestic product $(G D P)$, the stock market $(A S X)$, the yield on 3-month Treasury bills (3MTB), consumer confidence $(C O N S C O N F)$, and A $\$$ trade weighted index $(A U D T W I)$. The change in the level of the yield curve slope measure by the difference between 10-yr government bond and 3-month Treasury bill yields is also included (YieldCurve). Robust standard errors in parentheses.

${ }^{* * *},{ }^{* *},{ }^{*}$ denote significance at the $1 \%, 5 \%$, and $10 \%$ levels respectively. 
TABLE 7

Regression: Non-Linearity of Political Uncertainty Effect

\begin{tabular}{lcccccc}
\hline Variable & $\% \Delta \sigma_{S P X}$ & $\% \Delta \sigma_{S P X}$ & $\% \Delta \sigma_{10 Y B}$ & $\% \Delta \sigma_{10 Y B}$ & $\% \Delta \sigma_{A U D}$ & $\% \Delta \sigma_{A U D}$ \\
\hline Constant & -0.372 & -0.227 & 0.254 & 0.093 & -0.115 & 0.074 \\
& $(0.849)$ & $(0.707)$ & $(0.532)$ & $(0.443)$ & $(0.454)$ & $(0.379)$ \\
$\% \Delta E U$ & $0.521^{* * *}$ & $0.515^{* * *}$ & $0.278^{* * *}$ & $0.275^{* * *}$ & $0.227^{* * *}$ & $0.228^{* * *}$ \\
& $(0.156)$ & $(0.149)$ & $(0.098)$ & $(0.094)$ & $(0.080)$ & $(0.079)$ \\
$\% \Delta E U^{2}$ & $-0.006^{* *}$ & & $-0.007^{* *}$ & & $0.008^{* *}$ & \\
& $(0.003)$ & & $(0.003)$ & & $(0.003)$ & \\
$A R(1)$ & $-0.096^{*}$ & $-0.096^{*}$ & $-0.214^{* * *}$ & $-0.209^{* * *}$ & -0.008 & -0.008 \\
& $(0.049)$ & $(0.050)$ & $(0.051)$ & $(0.051)$ & $(0.051)$ & $(0.051)$ \\
& & & & & & \\
$\mathrm{R}^{2}$ & 0.219 & 0.212 & 0.061 & 0.060 & 0.043 & 0.042 \\
F-Stat & 5.189 & 7.754 & 8.255 & 12.251 & 2.970 & 4.173 \\
No. Obs & 386 & 386 & 386 & 386 & 386 & 386 \\
\hline
\end{tabular}

Note: This table presents results from the regression specification whereby the percentage change in implied volatility of SPX equity options, 10-yr bond options, and AUD currency options are regressed on the percentage change in the measure of political uncertainty (Election Uncertainty, $E U)$ and a quadratic term. One-lagged term of the dependent variable is also included. Robust standard errors in parentheses.

${ }^{* * *},{ }^{* *},{ }^{*}$ denote significance at the $1 \%, 5 \%$, and $10 \%$ levels respectively. 